GROUND-WATER RESOURCES OF ST. JOHNS COUNTY, FLORIDA

By RIck M. Spechler and Paul S. Hampson

U.S. GEOLOGICAL SURVEY

Water-Resources Invéstigations Report 83-4187

Prepared In cooperation with

ST. JOHNS COUNTY, FLORIDA

Tallahassee, Florida 


\section{UNITED STATES DEPARTMENT OF THE INTERIOR \\ WILIIAM P. CLARK, Secretary \\ GEOLOGICAL SURVEY \\ Dallas L. Peck, Director}

For additional information

write to:

District Chief

U.S. Geological Survey

Suite 3015

227 North Bronough Street

Tallahassee, Florida 32301
Copies of this report

can be purchased from:

Open-File Services Section Western Distribution Branch

U.S. Geological Survey

Box 25425, Federal Center

Denver, Colorado 80225

(Telephone: (303) 234-5888) 
CONTENTS

Page

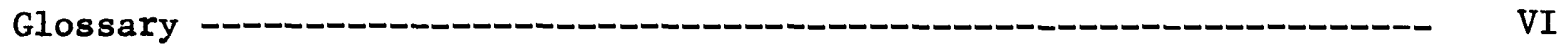

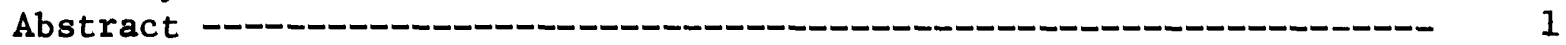

Introduction -- - - - -

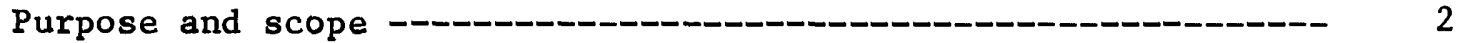

Previous investigations - - - - - -

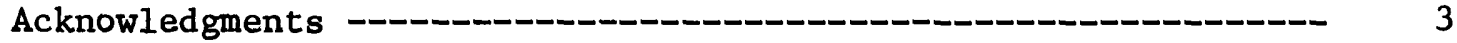

Description of study area - -

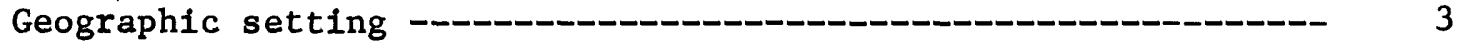

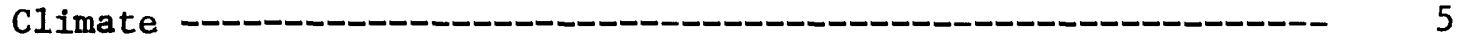

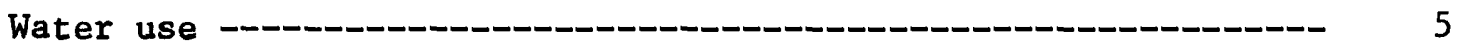

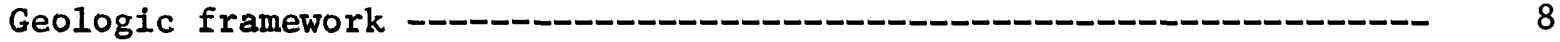

Ground water ---ー- - -

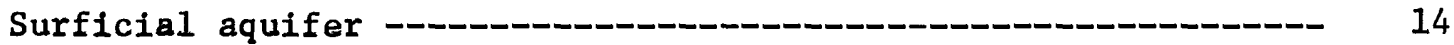

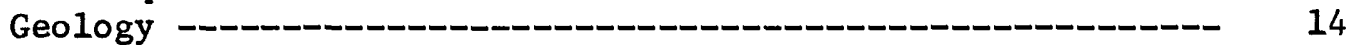

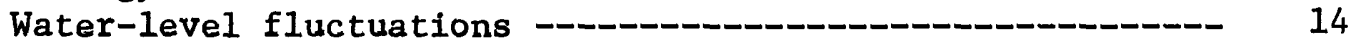

Hydraulic properties -----

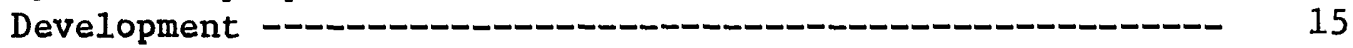

Floridan aquifer -- - - - - - - - - - - - -17

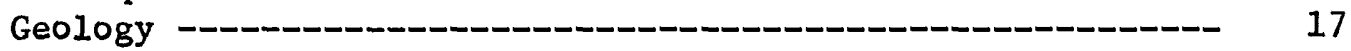

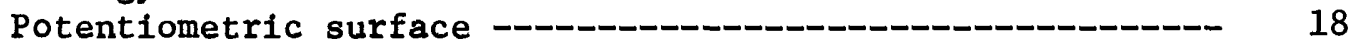

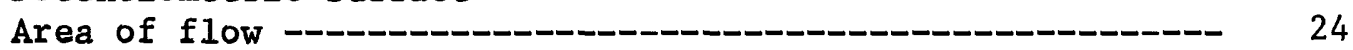

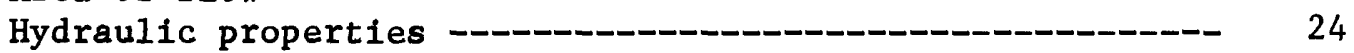

Development --ー-ー-ー-

Water quality - -

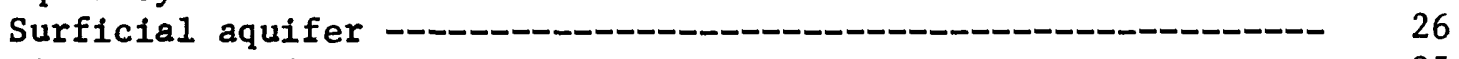

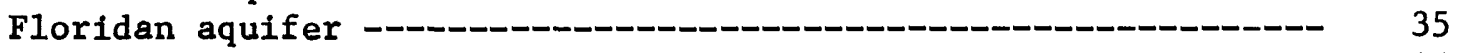

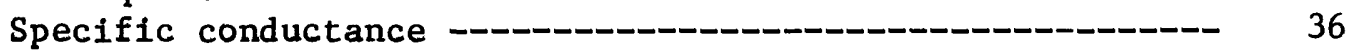

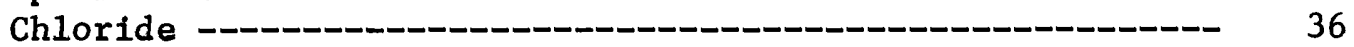

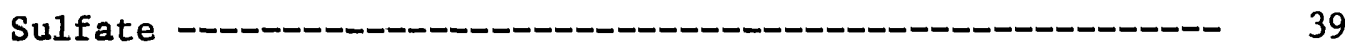

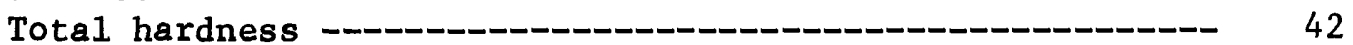

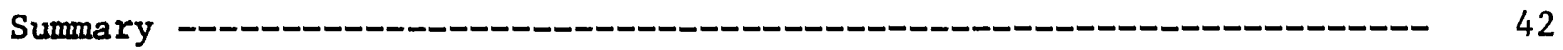

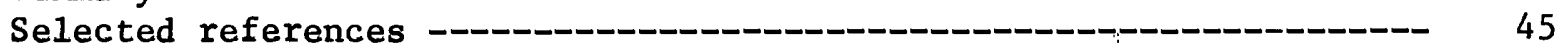

\section{ILLUSTRATIONS}

Page

Figure 1. Map showing St. Johns County, geographic features, and

2. Graphs showing average monthly rainfall at St. Augustine

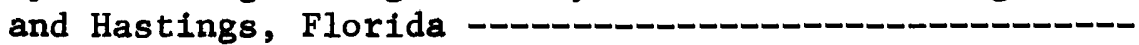

3. Map showing location of major public well fields -------

4. Geologic sections along lines $A-A^{\prime}$ and $B-B^{\prime}$

5. Map showing altitude of the top of the Floridan aquifer in St. Johns County --- 


\section{ILLUSTRATIONS (Continued)}

Page

Figure 6. Graphs showing water level in well 14 and rainfall at St. Augustine, March 1980 to June 1981

7. Map showing potentiometric surface of the Floridan aquifer in northeast Florida, September 1980

8. Map showing potentiometric surface of the Floridan aquifer in St. Johns County, September 1980

9. Map showing potentiometric surface of the Floridan aquifer in St. Johns County, May 1981

10. Hydrograph of we11 27

11. Areas of artesian flow of wells that tap the Floridan aquifer

12. Map showing distribution of specific conductance of water in the upper part of the Floridan aquifer, 1977-81

13. Map showing distribution of chloride concentrations of water in the upper part of the Floridan aquifer, 1977-81

14. Map showing distribution of chloride concentrations of water in the upper 200 feet of the Floridan aquifer, pre-1960

15. Map showing distribution of sulfate concentrations of water in the upper part of the Floridan aquifer, 1977-81

16. Map showing distribution of total hardness concentrations of water in the upper part of the Floridan aquifer, 1977-81

\section{TABLES}

Table 1. Estimated water use in St. Johns County, $1980 \ldots 7$

2. Geology of St. Johns County 10

3. Hydrogeologic framework _- 13

4. Source and significance of constituents and properties of water - 27

5. Recommended quality criteria for selected industrial and agricultural uses - 30

6. Recommended quality standards for public water supplies - 31

7. Chemical analyses of water from the surficial aquifer -.. 32

8. Chemical analyses of water from the Floridan aquifer -..- 33 


\section{CONVERSION FACTORS}

Factors for converting inch-pound units to International System of Units (SI) and abbreviations of units

\section{Multiply}

inch (in)

foot $(f t)$

mile (mi)

square mile $\left(\mathrm{mi}^{2}\right)$

acre

foot squared per day $\left(f t^{2} / d\right)$

gallon per minute (gal/min)

million gallon per day (Mgal/d)

degree Fahrenhelt $\left({ }^{\circ} \mathrm{F}\right)$

micromho per centimeter

at $25^{\circ}$ Celsius

(umho/ $\mathrm{cm}$ at $25^{\circ} \mathrm{C}$ )
By

$$
\begin{aligned}
& 25.4 \\
& 0.3048 \\
& 1.609 \\
& 2.590 \\
& 0.4047 \\
& 0.0929
\end{aligned}
$$

$3.7854 \times 10^{-3}$

0.04381

$5 / 9\left({ }^{\circ} \mathrm{F}-32\right)$

1.000
To obtain

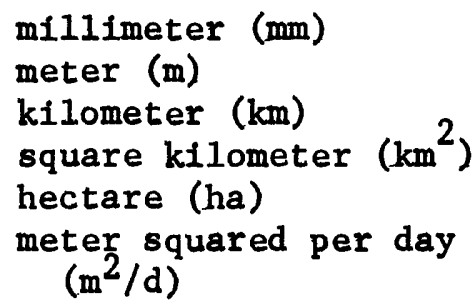

National Geodetic Vertical Datum of 1929 (NGVD of 1929): A geodetic datum derived from a general adjustment of the first-order level nets of both the United States and Canada, formerly called mean sea level, is referred to as sea level in this report. 


\section{GLOSSARY}

Terms related to ground water and water quality, as used in this report, are defined below.

Aquifer is a formation, group of formations, or part of a formation that contains sufficient saturated permeable material to yield significant quantities of water to wells and springs.

Confined aquifer is synonymous with artesian. A confined well is a well that derives its water from an artesian or confined water body. The water level in a confined well stands above the top of the confined water body it taps.

Confining bed is a body of relatively "impermeable" material stratigraphically adjacent to one or more aquifers.

Hydraulic conductivity is the rate at which water of the prevailing kinematic viscosity is transmitted through a unit area of aquifer at right angles to the direction of flow, under a unit hydraulic gradient.

Milligrams per liter (mg/L) is a unit for expressing the concentration of chemical constituents in solution. Milligrams per liter represents the weight of constituent per unit volume of water.

Potentiometric surface is a surface which represents the static head in an aquifer, defined by the levels to which water will rise in tightly cased wells.

Storáge coefficient is the volume of water an aquifer releases from or takes into storage per unit surface area of the aquifer per unit change in head.

Transmissivity is the rate at which ground water of the prevailing kinematic viscosity is transmitted through a unit width of an aquifer under a unit hydraulic gradient.

Water table is that surface in an unconfined ground-water body at which the pressure is atmospheric. It is defined by the levels at which water stands in wells that penetrate the water body just far enough to hold standing water. 


\title{
GROUND-WATER RESOURCES OF ST. JOHNS COUNTY, FLORIDA
}

By Rick M. Spechler and Paul S. Hampson

\begin{abstract}
The two primary sources of ground water in St. Johns County are the surficial and Floridan aquifers. The surficial aquifer is the principal source of water supply for drinking and domestic purposes in most of the county. The Floridan aquifer is the major source of water supply for irrigation use. In most of the county, water from the Floridan aquifer does not meet drinking water standards for some characteristics. Avallable supplies of potable water from the surficial aquifer are adequate to meet short-term increases in demand, but future growth will require additional sources of potable water.

The surficial aquifer is present throughout the county and extends from land surface to a maximum depth of about 120 feet. The aquifer is recharged primarily by rainfall and in some areas by infiltrating irrigation water withdrawn from the Floridan aquifer.

The Floridan aquifer underlies the county at a depth of about 90 to more than 360 feet below sea level. Recharge to the aquifer is almost entirely from the lake region in Alachua, southwestern Clay, eastern Bradford, and western Putnam Counties. Discharge is from springs, from wells used for irrigation, and by upward leakage.

Withdrawal of large quantities of water from the Floridan aquifer has caused declines in the potentiometric surface. During the spring, when withdrawal is heaviest and rainfall is 1ightest, the potentiometric surface is lowered an average of about 5 feet throughout the county and a maximum of about 15 feet in the agricultural areas. Comparison of predevelopment water levels with 1980 water levels indicates that withdrawals of water for irrigation and public supply have lowered the potentiometric surface about 10 to 20 feet throughout most of the county.

Water from the surficial aquifer generally meets most of the secondary drinking-water quality standards in most of the county and is satisfactory for most uses. Concentrations of sulfate and chloride generally do not exceed 250 milligrams per liter in St. Johns County, and only in a small part of the county do dissolved-solids concentrations exceed 500 milligrams per liter. Iron concentrations commonly exceed 0.3 milligrams per liter.
\end{abstract}


In most of St. Johns County, water from the Floridan aquifer is more saline than water from the surficial aquifer. Variations in the concentrations of chemical constituents occur both areally and with depth. Highly saline water is present in the upper part of the aquifer in most of the southern part of the county.

The presence of saline water and the dissolution of gypsum and anhydrite are the primary factors that govern water quality in the aquifer. In the southwest part of the county, intensive pumpage for irrigation has resulted in substantial increases in chloride concentration caused primarily from the upconing of more saline water.

\section{INTRODUCTION}

Rapid population and economic growth in St. Johns County during the past decade have resulted in water supply problems in some areas. Most of the growth has occurred in the coastal area where supplies of fresh ground water are limited. Since this growth is expected to continue, additional water supplies will be required to meet the projected demands.

The surficial aquifer and the Floridan aquifer are the two principal sources of ground water in St. Johns County. In 1980, withdrawals from these two aquifers accounted for 99.7 percent of the total water use in the county (Leach, 1982b). The Floridan aquifer, which is the principal source of water for most of northeast Florida, is extensively used for irrigation in the agricultural areas. In most of the southern half of the county, however, the Floridan aquifer ylelds highly saline water. The primary source of drinking water in St. Johns County is the surficial aquifer. Yields from wells that tap this aquifer, however, are much less than ylelds from wells that tap the deeper Floridan aquifer.

\section{Purpose and Scope}

This report presents the results of a 2-year study by the U.S. Geological Survey in cooperation with St. Johns County. The principal objective of the investigation was to provide basic hydrologic and geologic information to assist in the development and management of the ground-water resources of St. Johns County. The investigation was designed primarily to obtain data on the occurrence and quality of water in the surficial and Floridan aquifers.

This report includes a brief discussion of climate, a geologic description of the area, discussions of the occurrence and movement of ground water, properties of the aquifers, and the areal and temporal variations in ground-water quality and quantity. It also discusses the current use of water, some of the existing water quality problems, and the availability of ground water in St. Johns County. 
Previous Investigations

The geology and hydrology of St. Johns County have been discussed in several publications. Sellards (1907), Sellards and Gunter (1913), and Matson and Sanford (1913) briefly describe the ground-water resources of St. Johns County. Reports by Collins and Howard (1928), Stringfield (1936), Cooke (1945), Tarver (1958), Bentley (1977), Fairchild (1977), Hayes (1981), and Hampson and Hayes (1982), also describe the water resources of the county.

The most detalled and comprehensive investigations of the water resources of St. Johns County were a three-county investigation by Bermes and others (1963) and a four-county investigation by Frazee and McClaugherty (1979).

Much of the subsurface geology in the study area is described in reports by Vernon (1951), Puri (1957), Puri and Vernon (1964), and Chen (1965). Applin and Applin (1944) described the regional subsurface stratigraphy, paleontology, and etructure of Florida and southern Georgia.

\section{Acknowledgments}

The authors wish to express their appreclation for the assistance provided by the St. Johns County Commission and members of its staff. Particular acknowledgment is expressed to J. L. Harrington, County Administrator; and Gene Burns, Project Manager, St. Johns County.

Special appreciation is due to James Frazee, hydrologist, and Richard Johnson, geologist, of the St. Johns River Water Management District for furnishing data. Geologic data and drilling services provided by local well drillers are gratefully acknowledged. Thanks are also extended to the many residents of St. Johns County who permitted the sampling of water and measurement of water levels in their wells.

\section{DESCRIPTION OF STUDY AREA}

\section{Geographic Setting}

St. Johns County encompasses approximately 660 square miles (fig. 1) in the northeastern part of Florida (Marth and Marth, 1980). The county is bordered by Flagler County on the south, Putnam and Clay Counties on the west, Duyal County on the north, and the Atlantic Ocean on the east.

The county lies within the topographic division of the State known as the Coastal Lowlands (Cooke, 1945, p. 9). In general, land-surface altitudes range from sea level to about 45 feet; a maximum altitude of more than 65 feet occurs in the northern part of the county. The topography is controlled by a serles of marine terraces formed during the Plelstocene when sea levels were higher than at present. The terraces form a relatively flat plain that slopes eastward toward the Atlantic Ocean and westward toward the St. Johns River. The plain consists of a series of narrow sandy ridges and low intervening swampy areas that parallel the coast. In general, the altitude of the plain is less than 30 feet above sea level. East of the plain, there are coastal lagoons and salt marshes. Adjacent and parallel to the Atlantic shore, sand dunes reach a helght of almost 20 feet and extend in a narrow belt along the coast. 


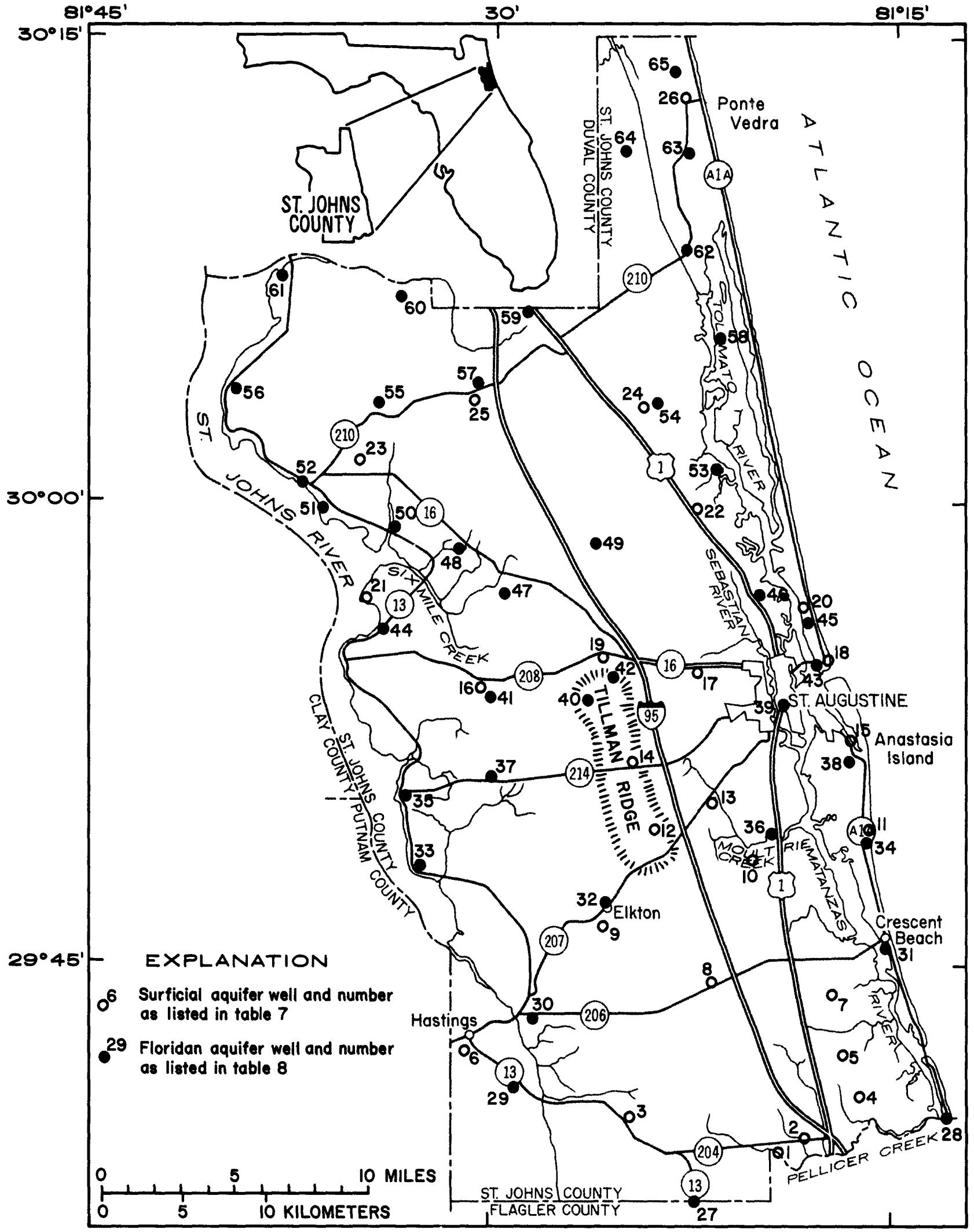

Figure 1.--St. Johns County, geographic features, and location of wells. 
Conover and Leach (1975) show that the major drainage divide extends from north to south through the center of St. Johns County. Surface drainage is not well developed in most of St. Johns County due to the relatively flat topography. There are a total of some 36 small tributary streams of which only 10 are more than 5 miles in length (Florida Board of Conservation, 1966). In the western part of the county, drainage is mainly through Six Mile Creek and smaller tributaries that drain into the St. Johns River. The eastern part of the county is drained by the Sebastian River, Moultrie Creek, and other tributaries that flow directly into the coastal lagoons and salt marshes that comprise the Tolomato and Matanzas Rivers. The Tolomato and Matanzas Rivers are part of the Intracoastal Waterway.

Much of the county is covered with pine forest and palmetto scrub interspersed with stands of hardwoods. Cypress stands are found in the swampy, more poorly drained areas. Approximately 292,000 acres, or 69 percent of the land, is covered by forest. About 8 percent of the land is used as cropland and improved pastureland; the mafor crops being potatoes and cabbage (Marella, 1982, p. 139). Extensive marsh areas along the eastern coast are covered by wetland grasses and shrubs.

The population of St. Johns County in 1940 was 20,000. By 1975, it had increased to 40,000, and by 1980 to 51,000. Most of the population is concentrated along the Atlantic coast and the St. Johns River. The largest metropolitan area in the county is the city of St. Augustine with a population of about 12,000 .

\section{Climate}

The-climate of the area is humid, subtropical, with warm, wet summers and mild, relatively dry winters. The average annual temperature is approximately $21^{\circ} \mathrm{C}$. December and January are normally the coldest months, with an average temperature of about $13^{\circ} \mathrm{C}$. July and August are the warmest, with an average temperature of $28^{\circ} \mathrm{C}$. Annual rainfall averages approximately 55 inches. Rainfall is unevenly distributed during the year, with over two-thirds falling during the 5-month period between June through October (fig. 2). The driest months during the year are November through May, with November generally being the month of lowest rainfall.

\section{Water Use}

Total water use in 1980 in St. Johns County was about $37.5 \mathrm{Mgal} / \mathrm{d}$ (Leach, 1982b), as shown in table 1. Approximately 99.7 percent of the total water used in the county was from ground-water sources. Irrigation of vegetables and pastureland in the farming communities around Hastings and Elkton accounted for about 79 percent of the total water used in the county. Virtually all this water was withdrawn from the Floridan aquifer, primarily during the dry season. 


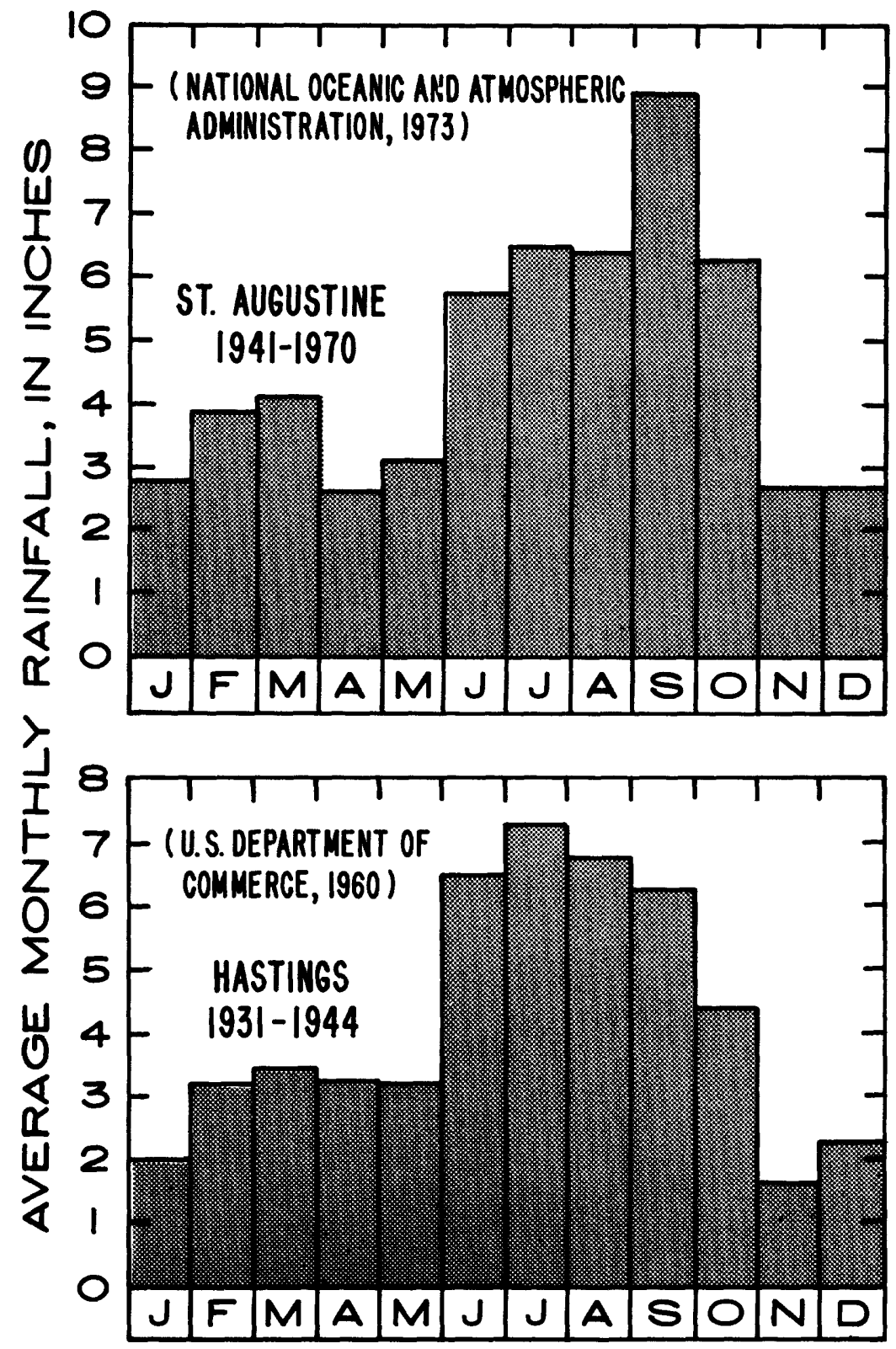

Figure 2.--Average monthly rainfall at St. Augustine and Hastings, Florida. 
Table 1.--Estimated water use in St. Johns County, 1980

$$
\text { [from Leach, 1982b] }
$$

$$
\text { Quantity used }
$$

Type of use

Public supply:

Ground water

Surface water

$$
2.98
$$

0

$$
\begin{aligned}
& 8.0 \\
& 0
\end{aligned}
$$

Rural (domestic and livestock):

Ground water

$$
4.81
$$

0.10

12.8

Surface water

0.01

0

0

Surface water

Irrigation:

Ground water

Surface water

29.55

0

78.9

0

Total 
The major source of water for drinking and other domestic uses in the county is the surficial aquifer. Of the six major public water supply systems in the county (fig. 3), only two (Ponte Vedra and Anastasia Sanitary District) obtain water from the Floridan aquifer. In 1980 these suppliers furnished $3.0 \mathrm{Mgal} / \mathrm{d}$ to about 49 percent of the county population. The remainder of the population obtains water from private domestic wells, mostly 2-inch wells that tap the surficial aquifer. The Floridan aquifer is a major source of public and rural supply in parts of the northern half of the county.

\section{GEOLOGIC FRAMEWORK}

St. Johns County is underlain by several thousand feet of marine sedimentary rocks that overlie a basement complex of metamorphic strata. The primary water-bearing sediments range in age from early Eocene to Holocene and are composed of limestone, dolomite, clay, and sand. The age, approximate thickness, and lithology of the stratigraphic units of interest in this study are shown in table 2 .

Sediments of Pleistocene and Holocene age deposited during the formation of marine terraces and beach ridges blanket all of St. Johns County. They are underlain in descending order by undifferentiated deposits of Pliocene and late Miocene age, the Hawthorn Formation of Miocene age, the Ocala Limestone of late Eocene age, and the Avon Park and Lake City Limestones of middle Eocene age. 01der and deeper rocks are not generally tapped by water wells in the study area because sufficient water can be obtained from the overlying formations and because the water from the deeper rocks is generally more saline. Variations in the thickness and distribution of the stratigraphic units are shown by geologic sections in figure 4. Locations of the sections are given in figure 5 .

\section{GROUND WATER}

Although all of the geologic units of interest present in St. Johns County yield some water to wells, their water-bearing characteristics differ considerably. Two major aquifers have been identified in St. Johns County, the surficial aquifer and the Floridan aquifer. The clays and marls of the Hawthorn Formation serve as a confining bed, separating the aquifers and confining water in the deeper Floridan aquifer under artesian pressure. Locally, permeable limestone lenses within the Hawthorn Formation yield sufficient quantities of water for domestic use. The Hawthorn, however, is not a major source of supply in St. Johns County. Table 3 gives a generalized summary of these geologic units as related to ground-water development. 


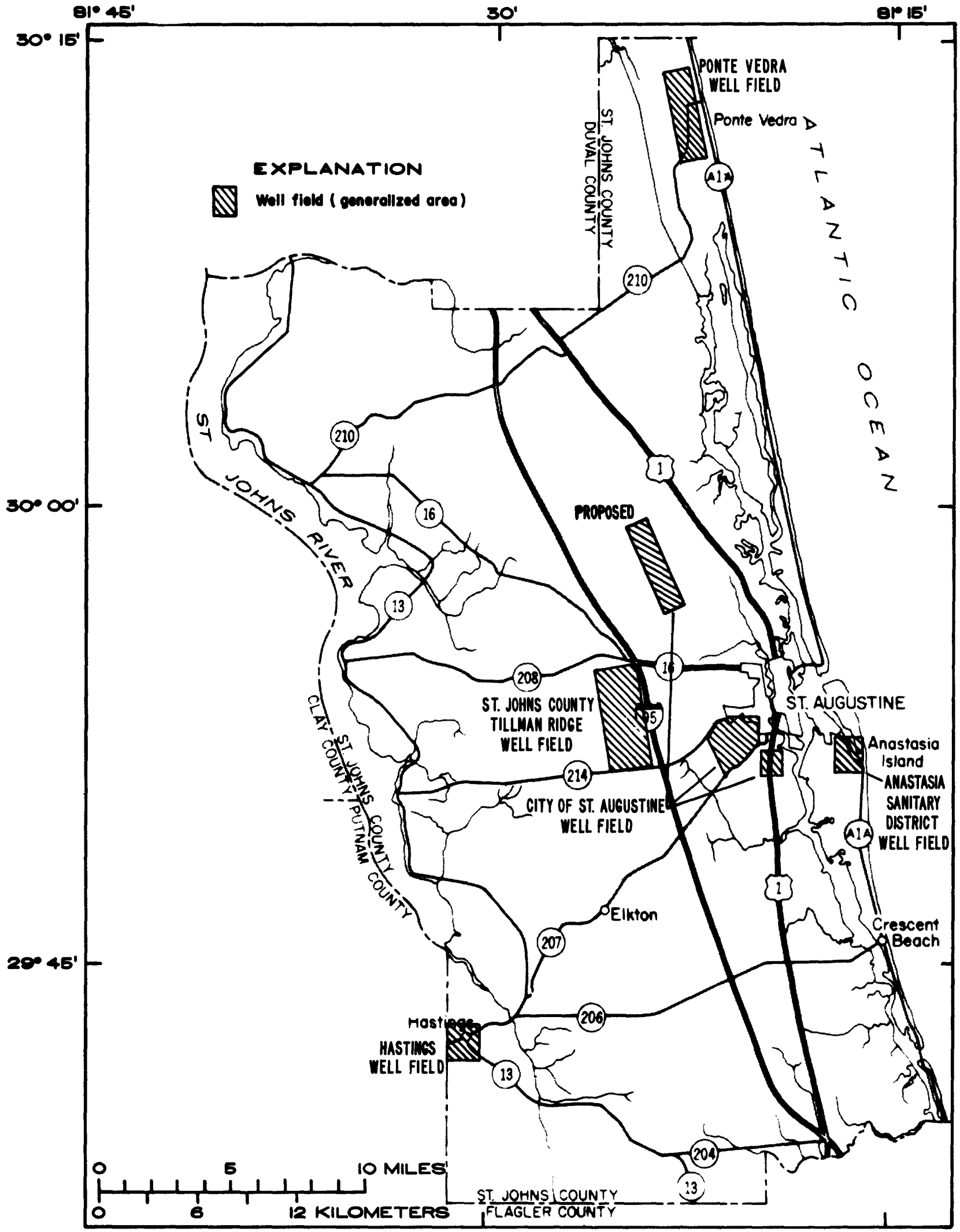

Figure 3.--Location of major public well fields. 
Table 2.-Geology of St. Johns County

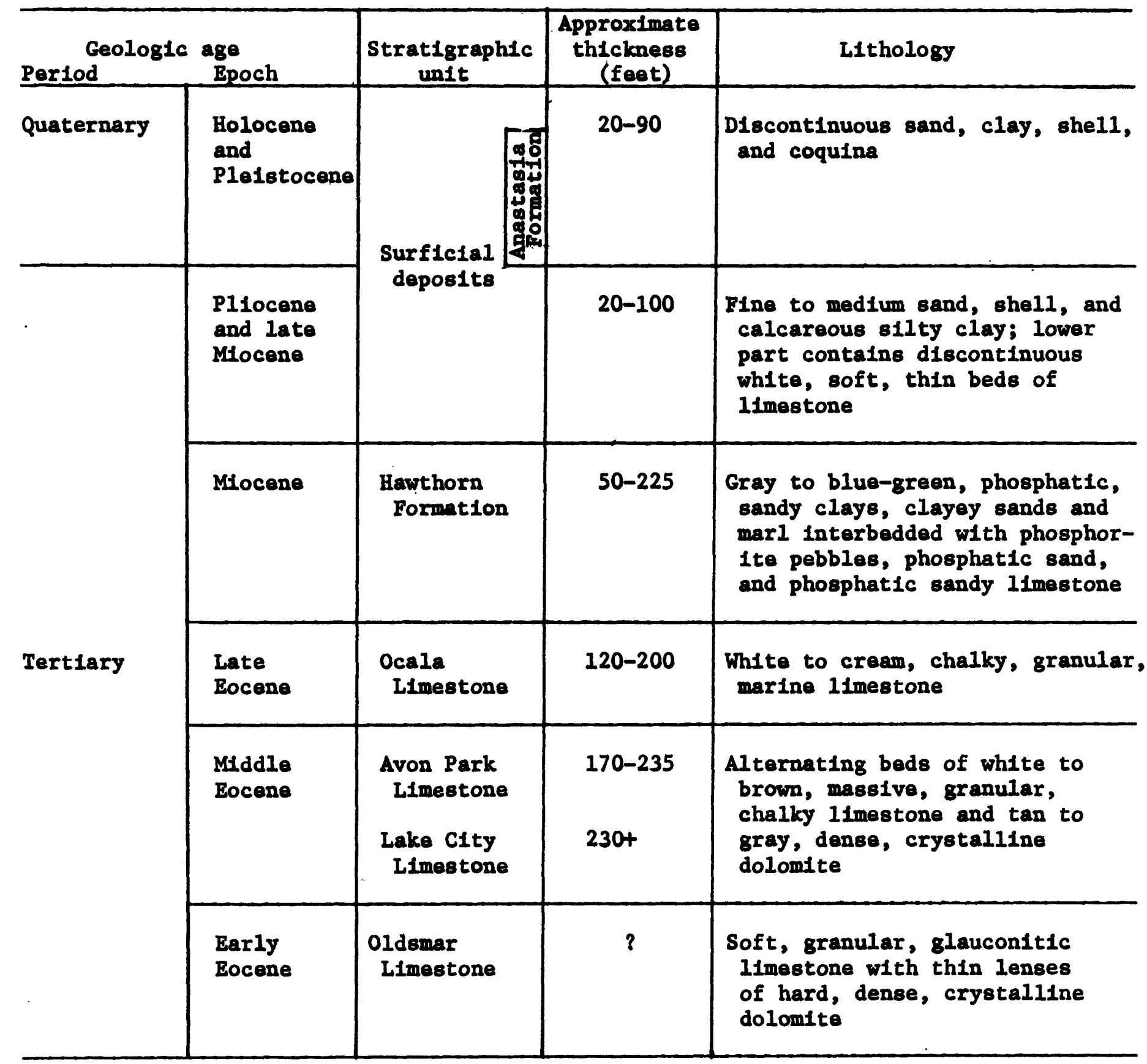




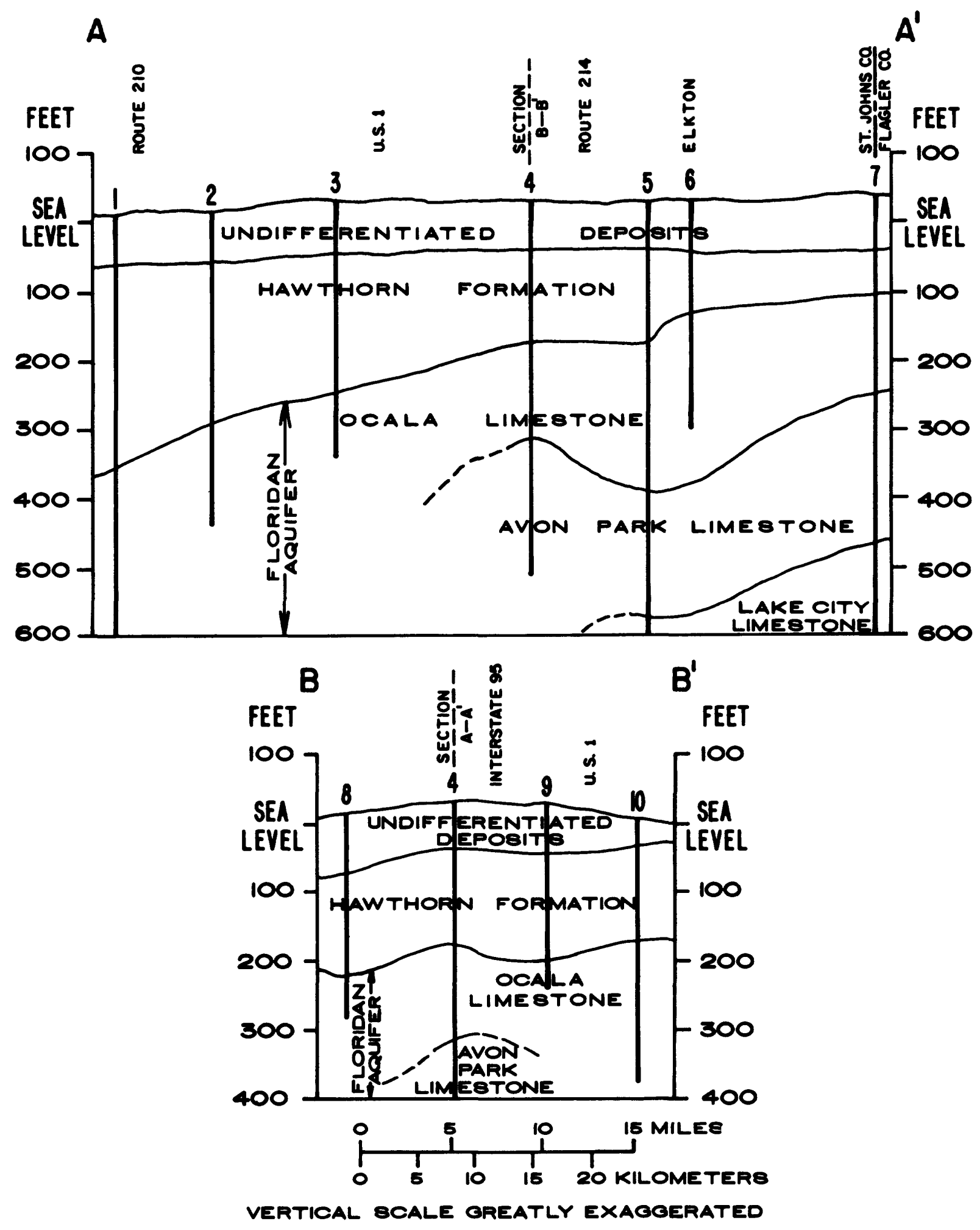

Figure 4.--Geologic sections along lines $A-A^{\prime}$ and $B-B^{\prime}$ (section lines shown in figure 5 ). 


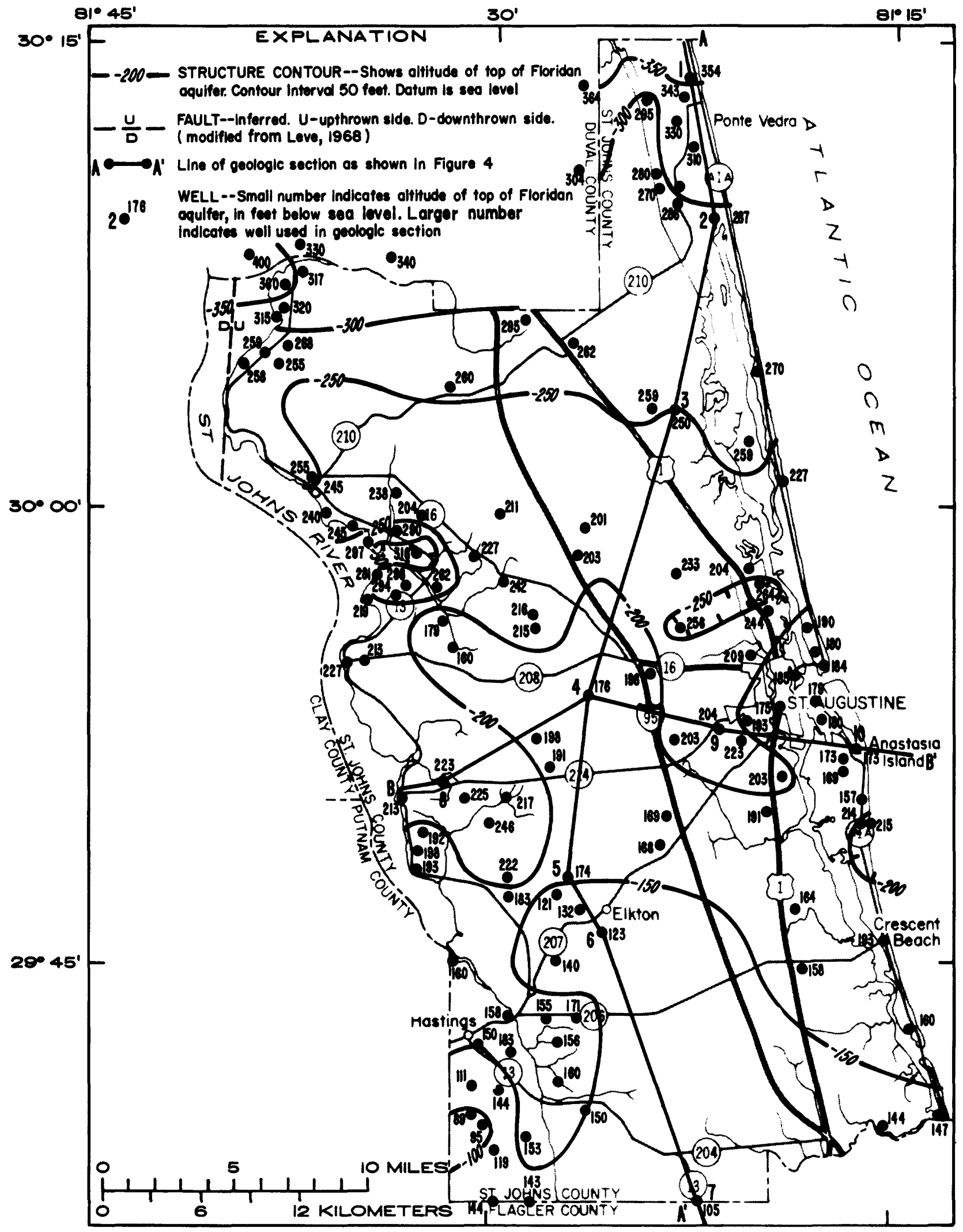

Figure 5.--Altitude of the top of the Floridan aquifer in St. Johns County (from Spechler, 1984). 
Table 3. - Hydrogeologic framework

\begin{tabular}{|c|c|c|c|}
\hline $\begin{array}{c}\text { Hydrogeologic } \\
\text { unit }\end{array}$ & $\begin{array}{c}\text { Equivalent } \\
\text { stratigraphic } \\
\text { unit } \\
\end{array}$ & $\begin{array}{l}\text { Approximate } \\
\text { yields } \\
\text { (gallons per } \\
\text { minute) } \\
\end{array}$ & $\begin{array}{r}\text { Water } \\
\text { uses } \\
\end{array}$ \\
\hline $\begin{array}{l}\text { Surficial } \\
\text { aquifer }\end{array}$ & $\begin{array}{r}\text { Surficial } \\
\text { deposits }\end{array}$ & $1-40$ & $\begin{array}{l}\text { Domestic, public } \\
\text { supply and lawn } \\
\text { irrigation }\end{array}$ \\
\hline $\begin{array}{l}\text { Confining } \\
\text { bed }\end{array}$ & $\begin{array}{l}\text { Hawthorn } \\
\text { Formation }\end{array}$ & $\begin{array}{l}\text { Yields small } \\
\text { amounts of } \\
\text { water from } \\
\text { permeable } \\
\text { limestone } \\
\text { lenses }\end{array}$ & Domestic \\
\hline \multirow{4}{*}{$\begin{array}{r}\text { Floridan } \\
\text { aquifer }\end{array}$} & $\begin{array}{l}\text { Ocala } \\
\text { Limestone }\end{array}$ & \multirow{4}{*}{$\begin{array}{l}\text { One hundred } \\
\text { to several } \\
\text { thousand }\end{array}$} & \multirow{3}{*}{$\begin{array}{l}\text { Crop irrigation, } \\
\text { stock watering, } \\
\text { domestic and } \\
\text { public supply }\end{array}$} \\
\hline & $\begin{array}{l}\text { Avon Park } \\
\text { Limestone }\end{array}$ & & \\
\hline & $\begin{array}{l}\text { Lake City } \\
\text { Limestone }\end{array}$ & & \\
\hline & $\begin{array}{l}\text { Oldsmar } \\
\text { Limestone }\end{array}$ & & $\begin{array}{l}\text { Not used due to } \\
\text { highly mineral- } \\
\text { Ized water }\end{array}$ \\
\hline
\end{tabular}




\section{Surficial Aquifer}

\section{Geology}

The sediments that make up the surficial aquifer range in age from late Miocene to Holocene. The aquifer underlies all of St. Johns County and generally consists of discontinuous and interbedded lenses of sand, she11, and clay. Locally, the uppermost beds of the Hawthorn Formation are hydraulically continuous with overlying deposits and form the lower part of the aquifer. The aquifer ranges in thickness from about 20 to 120 feet.

The physical characteristics of the Pleistocene and Holocene deposits are extremely variable. Along the southeast coast, shell beds within these deposits increase in thickness and are partially cemented to form a permeable coquina. This coquina, along with the unconsolidated beds of sand and shell at or near land surface, has been referred to as the Anastasia Formation of Pleistocene age (Cooke, 1945). The formation extends more than 150 miles south from St. Augustine but rarely extends inland beyond the Intracoastal Waterway. In much of the inland part of the county, discontinuous, relatively impermeable beds of dark brown-to-black hardpan occur near the surface. The layers of hardpan are composed of slightly to well-cemented carbonaceous sand and clay.

Underlying the undifferentiated Pleistocene and Holocene deposits are interbedded lenses of marine sediments consisting of fine-to-medium sand, shell, and green calcareous, sllty clay of Pliocene or late Miocene age. Unklesby (1945, p. 18) belleved that these beds were a continuation of Pliocene deposits exposed along the St. Johns River In Volusia County referred to as the Caloosahatachee Marl by Cooke and Mossom (1929, p. 152). In the lower part of the deposits, thin, discontinuous beds of soft, white, frlable limestone are present locally, particularly in the northern part of the county. The deposits uncomformably overlie the Hawthorn Formation in most of the county (Bermes and others, 1963 , p. 31). The unconformity is usually marked by a zone of phosphatic sediments. In parts of northern and eastern St. Johns County, however, Bermes and others (1963, p. 32) observed that the contact appeared to be gradational.

\section{Water-Level Fluctuations}

Water in the surficial aquifer is generally under unconfined, or water table conditions. Semiconfined conditions occur locally where clay beds or relatively impermeable hardpan overlie the aquifer. The configuration of the water table is generally similar to the surface topography. The depth to the water table ranges from less than 5 feet below land surface in the relatively flat low-lying areas to more than 10 feet below land surface in the topographically higher areas, such as along the coastal ridges. Water levels in 12 test wells drilled into the surficial aquifer in east-central St. Johns County (Hayes, 1981, p. 15) and in four in the southeast part of the county ranged from 1.5 to 14.5 feet below land surface: 
Major fluctuations of the water levels in the surficial aquifer occur in response to changes in rates of recharge and discharge, both natural and artificial. The surficial aquifer is recharged by the infiltration of rainwater, by water from lakes, streams, and marshes, and by upward leakage from the underlying artesian aquifers where the altitude of the potentiometric surface of the artesian aquifer is higher than the water table. Water is discharged from the surficial aquifer by evapotranspiration, pumpage, seepage into surface streams and swamps, and downward leakage where the water table is higher than the potentiometric surface of the underlying artesian aquifer. The seasonal relation between water levels in the surficial aquifer and rainfall variations is shown in. figure 6 . Water levels are generally highest from June to October during the rainy season and lowest from November to May during the dry season. However, water levels in figure 6 do not show this pattern due to a below normal and variable rainfall which occurred during most of 1980 and 1981.

\section{Hydraulic Properties}

Little information is available on the hydraulic properties of the surficial aquifer in St. Johns County. Hayes (1981, p. 14) determined a transmissivity of approximately 6,500 to $7,000 \mathrm{ft} / \mathrm{d}$ from an aquifer test at the Tillman Ridge well field. An investigation by $\mathrm{CH}_{2} \mathrm{M} \mathrm{Hilj}$ (1979, p. 2-12) reported values ranging from about 1,300 to $25,500 \mathrm{ft} / \mathrm{d}$. The unusually high value of $25,500 \mathrm{ft}^{2} / \mathrm{d}$ was determined for a permeable shell deposit that extended from about 35 feet to more than 95 feet below land surface. Transmissivities determined by Geraghty and Miller, Inc. (1976, p. 23) from five wells on northern Anastasia Island ranged from 1,750 to $18,500 \mathrm{ft}^{2} / \mathrm{d}$. These values collected by Geraghty and Miller were estimated from specific capacity values according to a method developed by Theis (1963). Variations in transmissivity are related primarily to changes in thickness, composition, and texture of the aquifer. The average storage coefficient for the aquifer in the Anastastia Island area was estimated to be about 0.1 (Geraghty and Miller, Inc., 1976, p. 24). Storage coefficients for watertable aquifers generally range from 0.05 to 0.3 (Ferris and others, 1962, P. 76-78).

\section{Development}

Hundreds of small-diameter wells tap the surficial aquifer in St. Johns County. Most wells are 2 inches in diameter and usually less than 100 feet in depth. Ylelds range from 1 to $40 \mathrm{gal} / \mathrm{min}$ and vary considerably with location, well construction, and depth. The highest yields are generally from wells that tap permeable sand and shell beds in the Pliocene and upper Miocene deposits. Wells that tap the shallower Pleistocene and Holocene deposits usually yleld $20 \mathrm{gal} / \mathrm{min}$ or less. In the southwest part of the county, yields are usually relatively small due to a higher proportion of clay in the aquifer. Small-diameter wells that tap the surficial aquifer are used primarily for lawn Irrigation and domestic supply in areas of the county not served by public systems. 

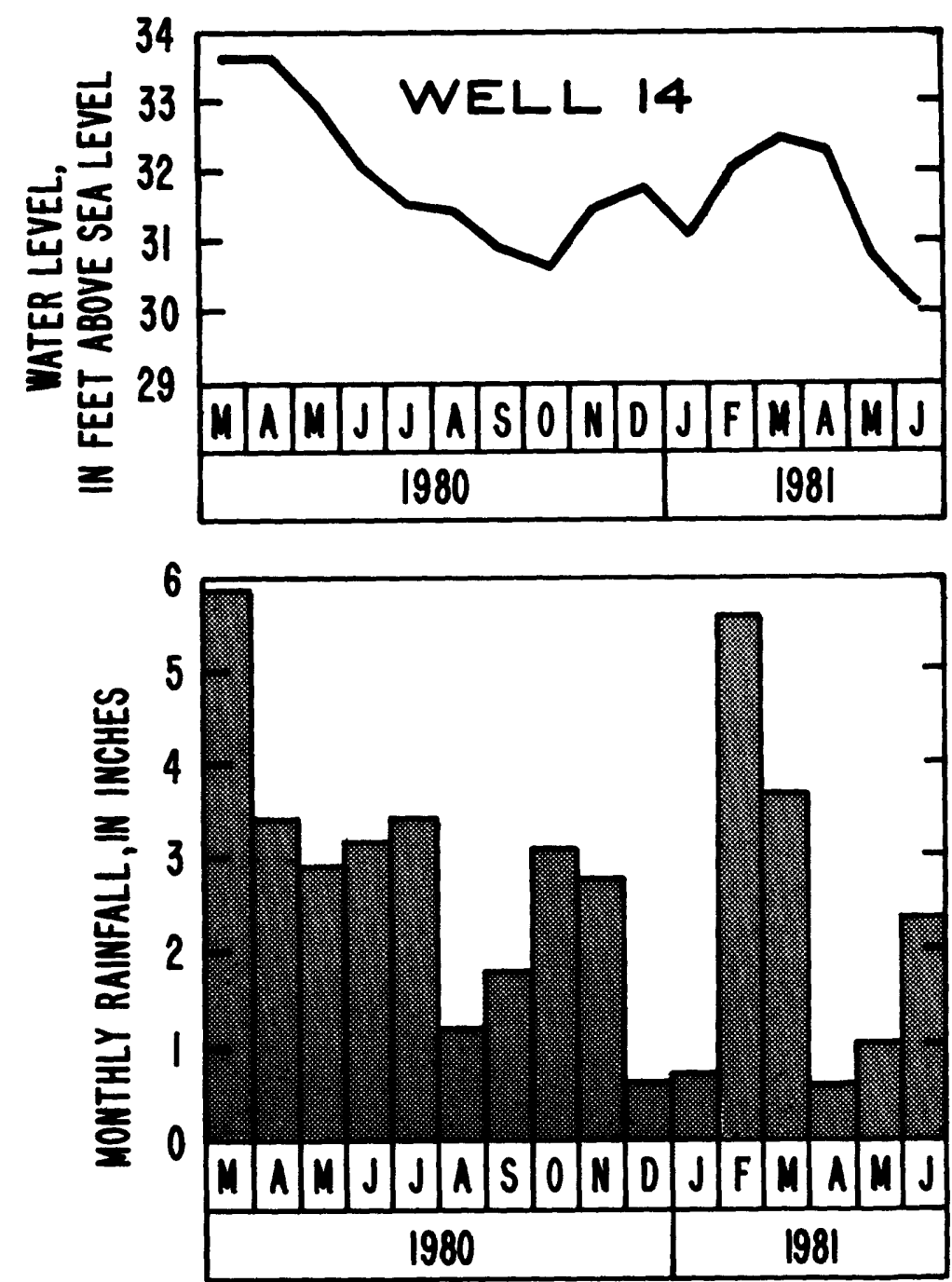

Figure 6.--Water level in well 14 and rainfall at St. Augustine, March 1980 to June 1981. 
Water demand for public supply is greatest along the coast south of St. Augustine and in the area served by the Hastings water system. Most public supply wells in the county are 4 to 6 inches in diameter and tap the Pliocene and upper Miocene deposits in the lower part of the aquifer. Six-inch wells that tap these deposits in east-central St. Johns County yield an average of $450 \mathrm{gal} / \mathrm{min}$. Similar yields are obtained from publicsupply wells that tap the coquina of. the Anastasia Formation along the southeast coast. In recent years, rapid urbanization in the coastal areas has greatly increased the demand for public supplies. The establishment of inland well fields has been necessary to help meet this increased demand in water use. Locations of existing well fields in St. Johns County are shown in figure 1. All, with the exception of the Ponte Vedra well field, use the surficial aquifer as the major source of public supply.

\section{Floridan Aquifer}

Geology

The Floridan aquifer, the most productive aquifer in St. Johns County, underlies all of Florida and parts of Alábama, Georgla, and South Carolina. It consists of a thick sequence of interbedded limestones and dolomites. In northeastern Florida, formations that comprise the aquifer are, in descending order, the Ocala, Avon Park, and Lake City Limestones. The aquifer is overlain by clays and marls of the Hawthorn Formation which serve as an upper confining unit. No water wells penetrate the Oldsmar Iimestone, and only a few wolls penetrate the Lake City Limestone in the county because water from these formations is very saline.

The altitude of the top of the Floridan aquifer, which usually corresponds to the top of the Ocala Limestone, is shown in figure 5. This upper surface is the remnant of an ancient karst plain and generally exhibits considerable irregularity throughout most of the county. The top of the aquifer ranges from about 90 feet below sea level in the southwest part of the county to more than 360 feet below sea level in the extreme northern part of the county.

Figure 5 also shows the location of an inferred fault in the northwestern part of the county. This north-south fault approximately parallels the St. Johns River and extends from central Duval County south to Green Cove Springs In Clay County (Fairchild, 1977, p. 23). According to Fairchild (1977, p. 21) most of the displacement along the fault has occurred in the pre-Miocene deposits, though some displacement has occurred in the Hawthorn Formation. The vertical displacement of the top of the Ocala Limestone along the fault is more than 100 feet (Fairchild, 1977, p. 23, 26).

Numerous faults and fracture patterns have been mapped by Vernon (1951, p. 47-48 and fig. 11) in the northern part of the State. One major fault and several of these fracture patterns extend into St. Johns County. Fractures related to faults or joint patterns may contribute locally to increases in the permeability of the limestone. These areas could also be subject to increases in mineralization of ground water because the faults and fractures could become avenues of upward migration of saline water from the deeper zones in the aquifer. 
The Ocala Limestone is predominantly a soft, white-to-cream, chalky-togranular, massive 1imestone. In the lower part of the unit, beds of foraminiferal coquina and thin discontinuous zones of gray-to-brown, hard crystalline dolomite occur. The thickness of the Ocala Limestone ranges from about 120 to 200 feet in St. Johns County.

The Avon Park Limestone unconformably underlies the Ocala Iimestone. It consists of alternating beds of tan to reddish-brown, massive-to-granular, lignitic, chalky, fossiliferous limestone, and brown-to-gray, hard, dense, crystalline dolomite. Near the base of the unit, hard beds of dolomite are usually found at the contact with the underlying Lake City Iimestone (Frazee and McClaugherty, 1979, p. 25). Bermes and others (1963, p. 25) found this contact marked by rounded pebbles of limestone and dolomite and by thin layers of white to green, calcareous clay. The unft ranges in thickness from about 170 to 235 feet.

The Avon Park Limestone is underlain unconformably by the Lake City Limestone. Few wells in the county penetrate the Lake City Limestone, so its thickness is undetermined. The formation generally consists of alternating beds of tan-to-gray, hard, dense, indurated, crystalline dolomite; white-to-brown, soft, porous, fossiliferous limestone; and brown-to-white, hard, dense, massive limestone (Bermes and others, 1963, p. 12). The formation contains beds consisting largely of microfossils and locally contains thin beds of lignite.

\section{Potentiometric Surface}

Figure 7 shows a generalized map of the potentiometric surface of the Floridan aquifer in northeast Florida for September 1980. The principal recharge area of the Floridan aquifer is the lake region of southwest Clay, eastern Bradford, Alachua, and western Putnam Counties. Within this recharge area water enters the Floridan aquifer by downward leakage where the semiconfining bed is thin or absent, by movement directly into the aquifer where it is near or exposed to land surface, and through breaches in the Hawthorn semiconfining bed caused by sinkholes. Clarke and others (1964, p. 125) report that recharge to the lake region is at a rate of about $45 \mathrm{Mgal} / \mathrm{d}$. Water is discharged from the Floridan aquifer in St. Johns County by pumpage and by upward leakage of water to the surficial aquifer where the potentiometric surface of the Floridan aquifer is above the water table.

Figures 8 and 9 show the potentlometric surface of the Floridan aquifer in St. Johns County during September 1980 and May 1981, representing conditions when water levels were generally at their highest and lowest, respectively. In most of the county the potentlometric surface was about 5 feet higher in September 1980 than In May 1981. 


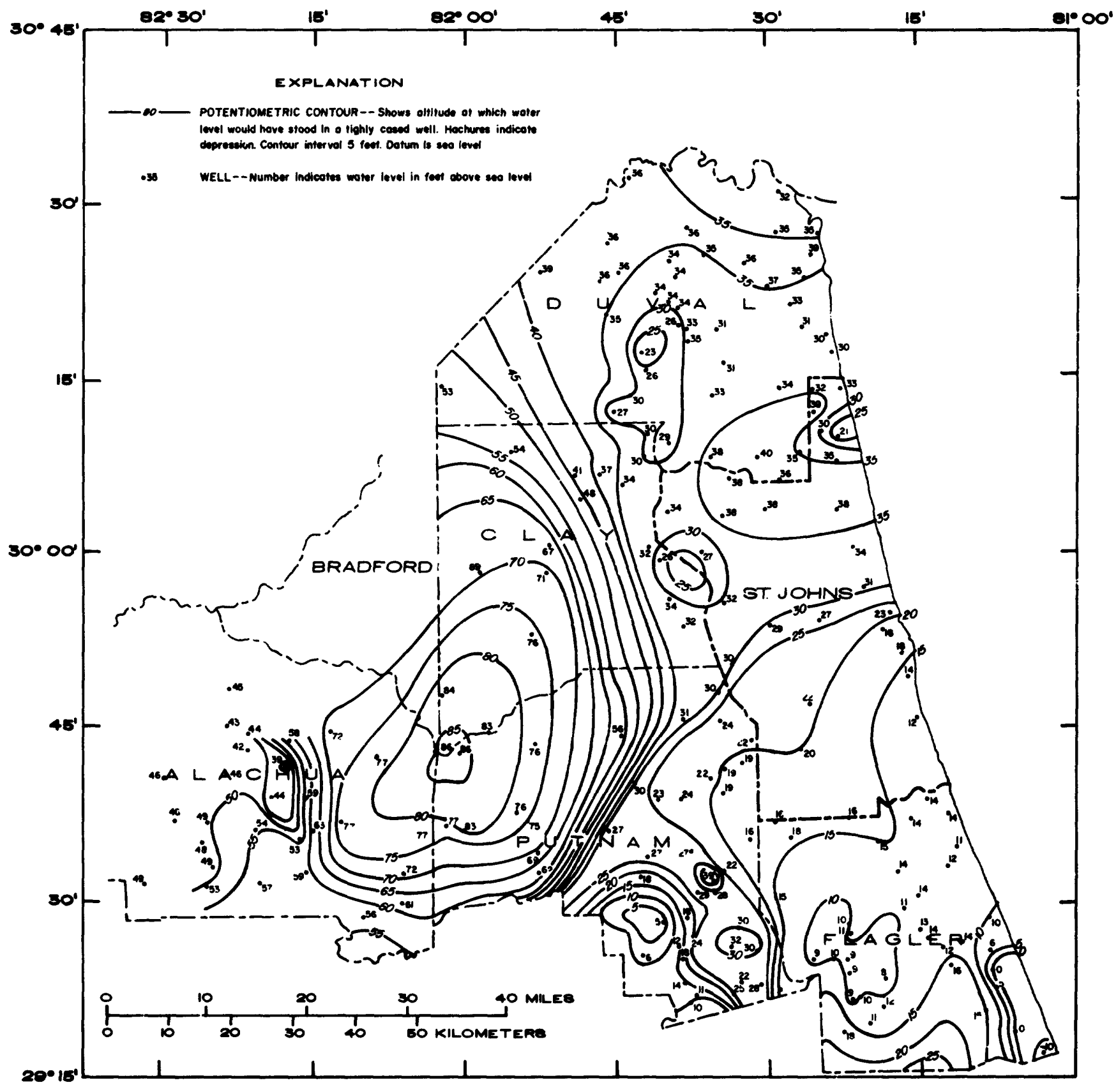

Figure 7.--Potentiometric surface of the Floridan aquifer in northeast Florida, September 1980 (from Schiner and Hayes, 1980). 


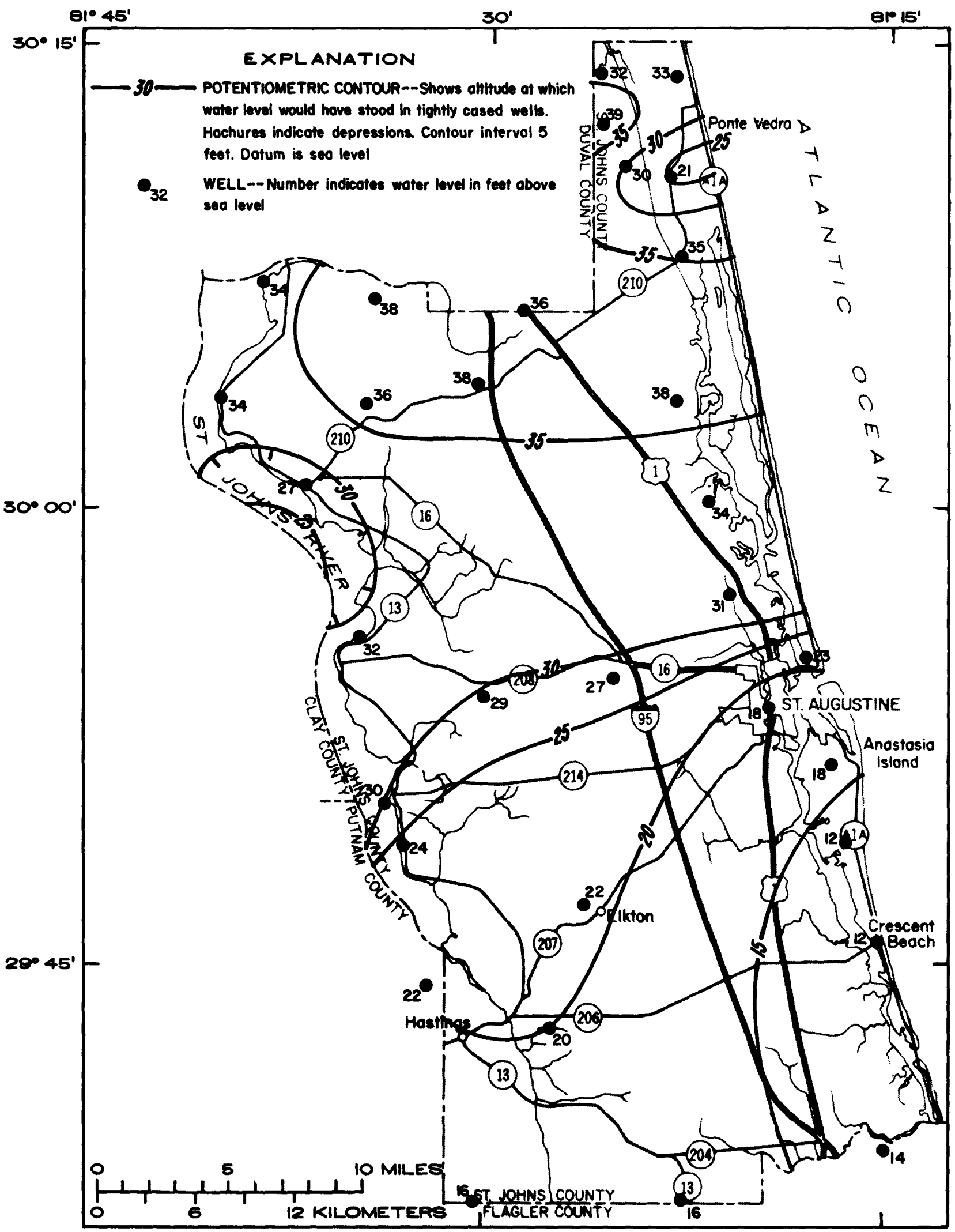

Figure 8.--Potentiometric surface of the Floridan aquifer in St. Johns County, September 1980 (from Schiner and Hayes, 1980). 


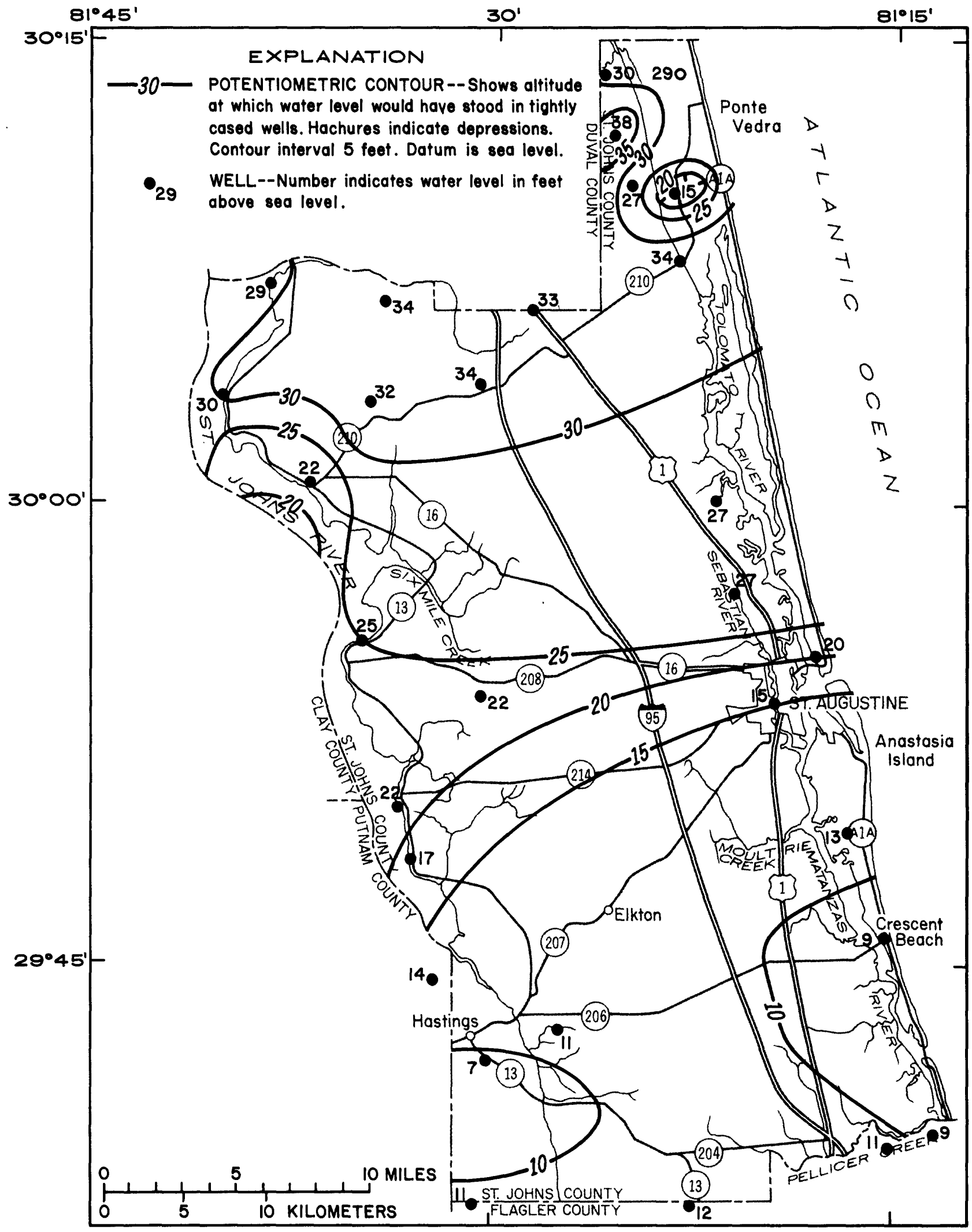

Figure 9.--Potentiometric surface of the Floridan aquifer in St. Johns County, May 1981 (from Schiner and Hayes, 1981). 
The potentiometric surface of the Floridan aquifer during May ranged from about 35 feet above sea level in the northern part of the county to less than 10 feet above sea level in the south. During September the range was from about 35 feet above sea level to less than 15 feet above sea level. The most prominent features on the potentiometric surface maps are two large depressions in the northern part of the county. The depression in northwest St. Johns County is the result of a combination of withdrawals from domestic and public-supply wells at Green Cove Springs, pumpage from Irrigation wells just south of the area, and flow from the spring at Green Cove Springs. It is possible that the discharge of undetected springs to the St. Johns River could contribute significantly to this depression in the potentiometric surface (Bentley, 1977, p. 28). The depression in northeast St. Johns County is in a rapidly developing area and is the result of pumpage for golf course irrigation and public supply.

In the southern half of the county, two additional areas of discharge are indicated on the May 1981 potentiometric surface map. Along the coast south of St. Augustine, the potentiometric surface slopes towards the southeast as a result of submarine discharge. A submarine spring about 2.5 miles east of Crescent Beach has been described by Stringfield and Cooper (1951, p. 63). It is probable that smaller, undetected springs south to Brevard County may also contribute to the discharge in this area (Stringfield and Cooper, 1951, p. 66). The depression in the potentiometric surface in the southwest part of the county in May is caused by pumpage from agricultural irrigation which occurs from late September through May.

The potentiometric surface is constantly fluctuating, mainly in response to changes in rates of recharge and discharge, and to a lesser extent, to earth tides, ocean tides, and changes in barometric pressure. Major fluctuations in the potentiometric surface in St. Johns County, however, are annual and respond to agricultural water use and to rainfall in the recharge areas. In most of the county, annual fluctuations are usually 5 feet or less. Fluctuations are greatest where the aquifer is heavily pumped for irrigation, particularly during the dry season. Between late March and early April, short term fluctuations of as much as 16 feet have been observed in wells near Hastings (Frazee and McClaugherty, 1979, p. 37). Water-level changes from 1965 to 1981 are shown in a hydrograph of well 27 (fig. 10), located in the southern part of St. Johns County. Water l'evels are generally highest from June to October, during periods of high rainfall and minimum pumpage, and lowest from March to May, during periods of low rainfall and maximum pumpage. This downward trend of the potentiometric surface is usually reversed when the rainy season begins and pumpage decreases. During this period, water levels generally rise rapidly, often several feet or more in 1 or 2 weeks.

Comparison of a regional predevelopment map of the estimated potentiometric surface (Johnston, and others, 1980) with the September 1980 potentiometric surface map of St. Johns County indicates a decline over most of the county ranging from about 10 to 15 feet. These declines were caused primarily by an increase in agricultural and regional water use. In the extreme northeast part of the county, however, heavy pumpage for golf course irrigation and public supply has produced declines of more than 20 feet. Examination of the hydrograph of well 27, located on the St. Johns-Flagler County 1ine, shows a general decline of about 2 to 3 feet since 1965, a condition probably representative of the potentiometric surface in that part of the county. 


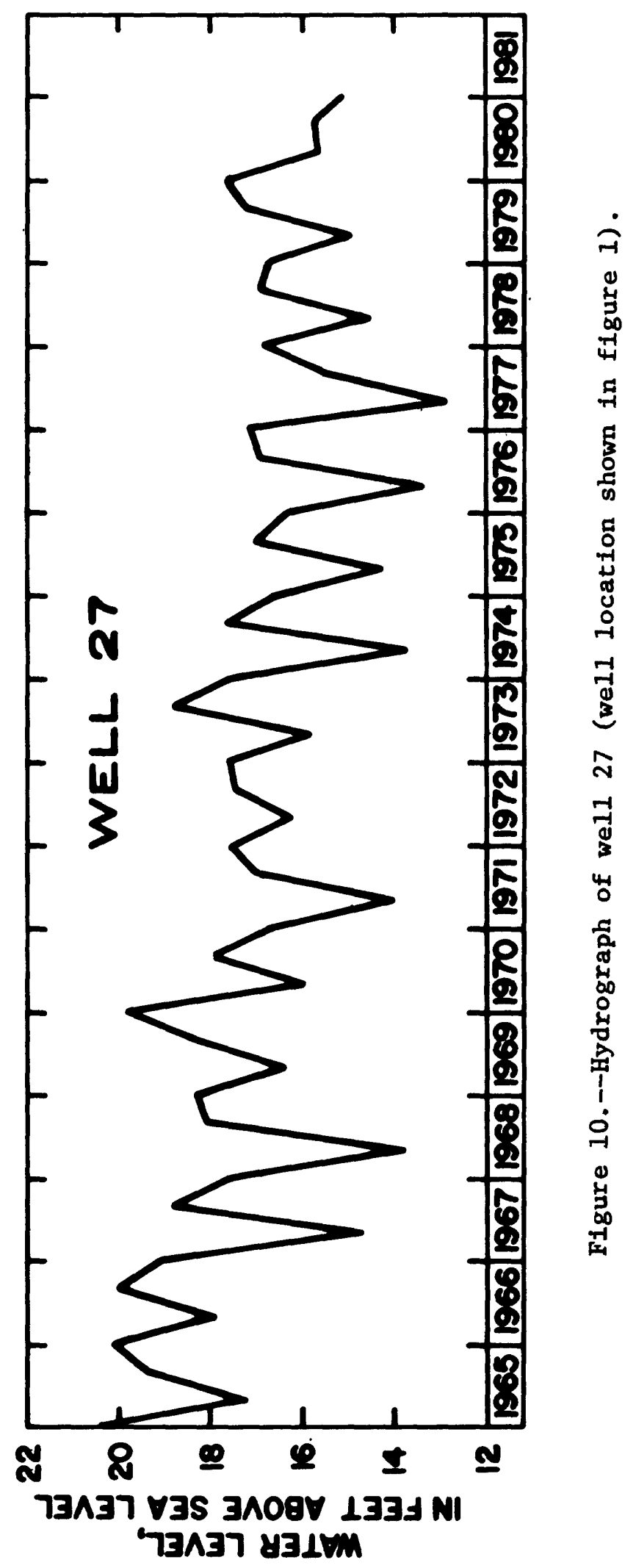


In all of St. Johns County, the Floridan aquifer is confined beneath the less permeable Hawthorn Formation and is under artesian pressure. Wells that tap the Floridan aquifer will flow in areas where the potentiometric surface of the aquifer is above land surface. Figure 11 shows the approximate areas of artesian flow in St. Johns County. The area of artesian flow covers a narrow strip along the coast south of St. Augustine, that extends inland several miles along Pellicer Creek and its tributaries. North of St. Augustine, the area of artesian flow extends across all of northern St. Johns County. The area of flow extends southward along the St. Johns River valley and its tributaries and narrows north of Hastings.

The most prominent area of intermittent flow is around the farming areas of southwest St. Johns County. In this area the topography has little relief, and the potentiometric surface is at about the same altitude as the land surface. Small declines in the altitude of the potentiometric surface can reduce the area of flow by several miles (Bermes and others, 1963 p. 64).

\section{Hydraulic Properties}

Varlations in transmissivity appear to occur throughout the upper part of the Floridan aquifer in St. Johns County. Quantitative information on most of the aquifer properties, however, is scattered and incomplete. Bentley (1977, p. 37) determined transmissivity values ranging from 1,600 to $56,000 \mathrm{ft}^{2} / \mathrm{d}$ from nine locations in the county. Bermes and others (1963, p. 67) reported transmissivity values ranging from 23,000 to $39,000 \mathrm{ft}^{2} / \mathrm{d}$. Tests conducted by Bentley (1977, p. 37) and Bermes and others (1963, p. 67) also showed storage coefficients of the aquifer to average about $1.0 \times 10^{-4}$. The storage coefficient for artesian aquifers usually ranges from about $1.0 \times 10^{-5}$ to $1.0 \times 10^{-3}$ and is about $1.0 \times 10^{-6}$ per foot of aquifer thickness (Lohman, 1979, p. 8).

\section{Development}

The Floridan aquifer yields abundant supplies of water to hundreds of wells in St. Johns County. Ylelds range from about $100 \mathrm{gal} / \mathrm{min}$ from 2 to 4 inch diameter wells to several thousand gal/min from 8 to 12 inch diameter wells. Most wells that tap the aquifer in St. Johns County are 4-inch diameter or larger cased to the top of the Iimestone, and finished as open holes into the limestone formation. The aquifer serves as a source of potable water in much of the northern part of the county. The predominant use of the aquifer, however, is for Irrigation in the agricultural areas near Hastings and E1kton. 


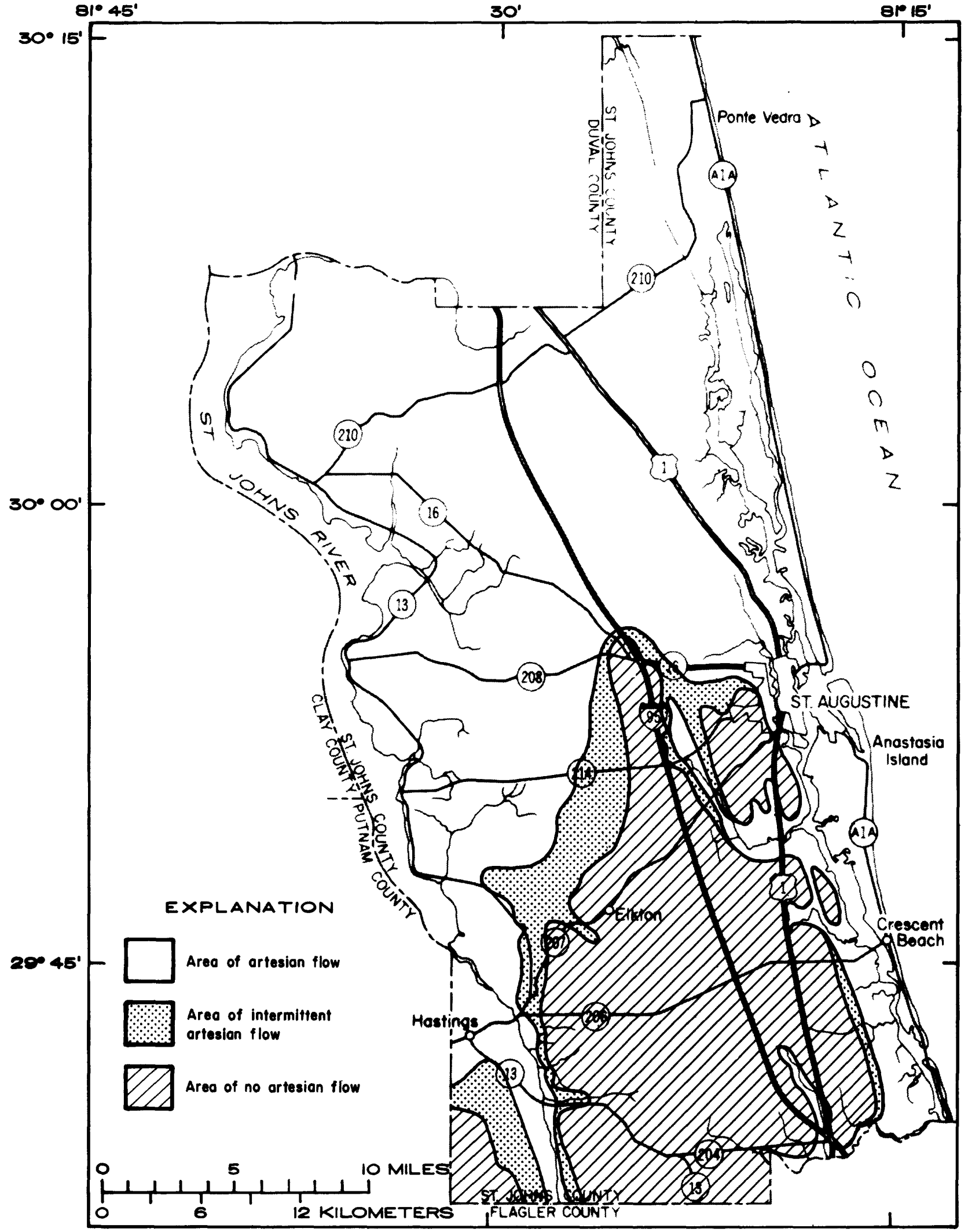

Figure 11.--Areas of artesian flow of wells that tap the Floridan aquifer (from Munch and others, 1979a). 


\section{WATER QUALITY}

The distribution and abundance of chemical characteristics and physical properties of ground water are affected by many factors including the initial chemical composition of water entering the aquifers, the types of rocks with which it comes in contact, and the length of time it remains in contact with the rock. Other sources of chemical constituents in ground water include seawater, connate water (water trapped in the rocks during their formation), and contaminated water. The areal distribution of chemical constituents is also determined by the ground-water flow patterns.

The sources and significance of selected chemical constituents and properties of water are given in table 4, and recommended criteria for a few of the water-quality parameters for agriculture and industrial purposes are given in table 5 (National Academy of Sciences and National Academy of Engineering, 1974). The U.S. Environmental Protection Agency (1975, 1977a) has developed both primary drinking water standards, which are mandatory for public supply, and secondary standards, which may be exceeded only if no other supply is avallable. It should be noted that the constituents determined during this study, with the exception of fluoride, pertain only to the secondary drinking water standards (table 6).

During this investigation, water samples were collected from 65 wells In St. Johns County; 26 wells tapped the surficial aquifer and 39 wells tapped the Floridan aquifer (fig. 1). All water samples were analyzed by the U.S. Geological Survey National Water-Quality Laboratory-Atlanta in Doraville, Ga. The results of the chemical analyses are shown in tables 7 and 8. Several analyses made by the St. Johns RIver Water Management District from 1978 to 1980 are also included in the tables and are so noted.

\section{Surficlal Aquifer}

The results of chemical analyses of water from the surficlal aquifer in St. Johns County are given in table 7. Well locations are shown in figure 1. In general, water from the surficlal aquifer meets the secondary standards recommended by the U.S. Environmental Protection Agency (1977a) and the primary fluoride standard (U.S. Environmental Protection Agency, 1975). Iron and chloride concentrations exceed the respective limits, however, in some locales.

The concentrations of most chemical constituents in water from the surficlal aquifer in St. Johns County are variable and highly dependent upon the local geologic and hydrologic conditions. For example, total hardness concentrations ranged from 150 to $410 \mathrm{mg} / \mathrm{L}$, sulfate concentrations from less than 1.0 to $180 \mathrm{mg} / \mathrm{L}$, sodium concentrations from 8 to $180 \mathrm{mg} / \mathrm{L}$, and chloride concentrations from 9.3 to $310 \mathrm{mg} / \mathrm{L}$. In most of the county, varlations occur over relatively small distances (less than 1,000 feet) and reflect difference in aquifer composition and the residence time of the ground water. In the coastal areas, the water quality in the aquifer is affected by the degree of interconnection of the aquifer with the sea or the Intracoastal Waterway. 
Table 4.--Source and significance of constituents and properties of water

[Modified from U.S. Geological Survey 1978]

Constituent or property

Source or cause

Significance

Bicarbonate $\left(\mathrm{HCO}_{3}\right)$ and Carbonate $\left(\mathrm{CO}_{3}\right)$

Calcium (Ca) and Magnesium (Mg)

Chloride (C1)

Dissolved sollds
Produced by reaction of atmospheric carbon dioxide with water. Dissolved from carbonate rocks such as limestone and dolomite.

Dissolved from practically all solls and rocks, but especially from limestone, dolomite, and gypsum. Calcium and magnesium are found in large quantities in some brines. Magnesium is present in large quantities in seawater.

Dissolved from rocks and soils. Present in sewage and found in large amounts in ancient brines, seawater, and industrial brines.

Chiefly mineral constituents dissolved from weathering of rocks and soils.
Bicarbonate and carbonate produce alkalinity. Bicarbonates of calclum and magnesium decompose in steam bollers and hot water facilities to precipitate as scale and release corrosive carbon dioxide gas. In combination with calcium and magnesium cause carbonate hardness.

Cause most of the hardness and scale-forming properties of water; consume soap (see hardness). Water low in calcium and magnesium are desired in electroplating, tanning, dyeing, and in textile manufacturing.

About $300 \mathrm{mg} / \mathrm{L}$ in combination with sodium gives salty taste to water. Increases the corrosiveness of water. U.S. Environmental Protection Agency drinking water standards (1977a) recommend that the chloride concentration should not exceed $250 \mathrm{mg} / \mathrm{L}$.

The U.S. Environmental Protection Agency (1977a) recommends that the dissolved solids should not exceed $500 \mathrm{mg} / \mathrm{L}$, however, $1,000 \mathrm{mg} / \mathrm{L}$ is permitted under certain circumstances. Waters containing more than $1,000 \mathrm{mg} / \mathrm{L}$ of dissolved solids are unsuitable for many purposes. The U.S. Geological Survey classifies the degree of salinity of water as follows:

Dissolved solids (mg/L): less than 1,000 , nonsaline; 1,000 to 3,000 , slightly saline; 3,000 to 10,000 , moderately saline; 10,000 to 35,000 , very saline; more than 35,000 , brine. 
Table 4.--Source and significance of constituents and properties of water--Continued

Constituent or property

Fluoride (F)

Total hardness $\left(\mathrm{as} \mathrm{CaCO}_{3}\right)$

Iron (Fe)
Dissolved in small to minute quantities from most rocks and soils. Enters many waters from fluoridation of municipal supplies.

In most waters nearly all the hardness is due to calcium and magnesium. All of the metallic cations other than the alkali metals also cause hardness
Iron is dissolved from many rocks and soils. On exposure to air normal basic waters that contain more than $1 \mathrm{mg} / \mathrm{L}$ of 1 ron soon become turbid with the insoluble reddish ferric compounds produced by oxidation. Surface waters, therefore, seldom contain as much as $1 \mathrm{mg} / \mathrm{L}$ of dissolved iron, although some acid waters carry large quantities of iron in solution,
SIgnificance

Fluoride in drinking water reduces the incidence of tooth decay when the water is consumed during the period of enamel calcification. However, it may cause mottling of teeth depending on the concentration of fluoride, the age of the child, amount of drinking water consumed, and susceptibility of the individual.

Consumes soap before a lather will form. Deposits soap curd on bathtubs. Hard water forms scale in bollers, water heaters, and pipes. Hardness equivalent to the bicarbonate and carbonate is called carbonate hardness. Any hardness in excess of this is called noncarbonate hardness. Waters of hardness up to $60 \mathrm{mg} / \mathrm{L}$ are considered soft; 61 to $120 \mathrm{mg} / \mathrm{L}$, moderately hard; 121 to $200 \mathrm{mg} / \mathrm{L}$, hard; more than $200 \mathrm{mg} / \mathrm{L}$, very hard.

On exposure to air, fron in ground water oxidizes to reddish-brown sediment. More than about $300 \mathrm{ug} / \mathrm{L}$ may stain laundry and utensils reddish-brown. objectionable for food processing, textile processing, beverages, ice manufacture, brewing and other processes. U.S. Environmental Protection Agency drinking water standards state that for esthetic reasons iron and manganese should not exceed $300 \mathrm{ug} / \mathrm{L}$. Larger quantities cause unpleasant taste and favor growth of iron bacteria. 
Table 4.-- Source and significance of constituents and properties of water--Continued

\begin{tabular}{|c|c|c|}
\hline Constituent or property & Source or cause & Significance \\
\hline $\begin{array}{l}\text { Sodium (Na) and } \\
\text { Potassium (K) }\end{array}$ & $\begin{array}{l}\text { Dissolved from practically all } \\
\text { rocks and soils. Found also } \\
\text { in ancient brines, seawater, } \\
\text { industrial brines, and sewage. }\end{array}$ & $\begin{array}{l}\text { Large amounts, in combination } \\
\text { with chloride, give a salty } \\
\text { taste. Moderate quantities } \\
\text { have little effect on the } \\
\text { usefulness of water for most } \\
\text { purposes. Sodium salts may } \\
\text { cause foaming in steam boilers } \\
\text { and a high sodium concentration } \\
\text { may limit the use of water for } \\
\text { irrigation. }\end{array}$ \\
\hline $\begin{array}{l}\text { Specific conductance } \\
\text { (micromhos at } 25^{\circ} \mathrm{C} \text { ) }\end{array}$ & $\begin{array}{l}\text { Mineral concentration of the } \\
\text { water. }\end{array}$ & $\begin{array}{l}\text { Indicates degree of mineraliza- } \\
\text { tion. Specific conductance is } \\
\text { a measure of the capacity of } \\
\text { the water to conduct an electric } \\
\text { current. Varies with concentra- } \\
\text { tion and degree of ionization of } \\
\text { the constituents. }\end{array}$ \\
\hline Sulfate $\left(\mathrm{SO}_{4}\right)$ & $\begin{array}{l}\text { Dissolved from rocks and soils } \\
\text { containing gypsum, lron sulfides, } \\
\text { and other sulfur compounds. Us- } \\
\text { ually present in mine waters and } \\
\text { in some industrial waters. }\end{array}$ & $\begin{array}{l}\text { Sulfate in water containing } \\
\text { calcium forms hard scale in } \\
\text { steam boilers. In large } \\
\text { amounts, sulfate in combination } \\
\text { with other ions gives bitter } \\
\text { taste to water. Some calcium } \\
\text { sulfate is considered benefi- } \\
\text { clal in the brewing process. } \\
\text { U.S. Environmental Protection } \\
\text { Agency drinking water standards } \\
\text { recommend that the sulfate con- } \\
\text { centration should not exceed } \\
250 \mathrm{mg} / \mathrm{L} \text {. }\end{array}$ \\
\hline
\end{tabular}

Specific conductance (micromhos at $25^{\circ} \mathrm{C}$ )

Dissolved from rocks and soils containing gypsum, Iron sulfides, and other sulfur compounds. Usually present in mine waters and in some industrial waters.
Large amounts, in combination with chloride, give a salty purposes. Sodium salts may cause foaming in steam boilers may limit the use of water for irrigation.

Indicates degree of mineralizaion. Specific conductance is measure of the capacity of tion and degree of ionization of Sulfate in water containing calcium forms hard scale in eam boilers. In large ounts, sulfate in combination oulfate is considered beneficlal in the brewing process. U.S. Environmental Protection Agency drinking water standards recommend that the sulfate concentration should not exceed $250 \mathrm{mg} / \mathrm{L}$. 


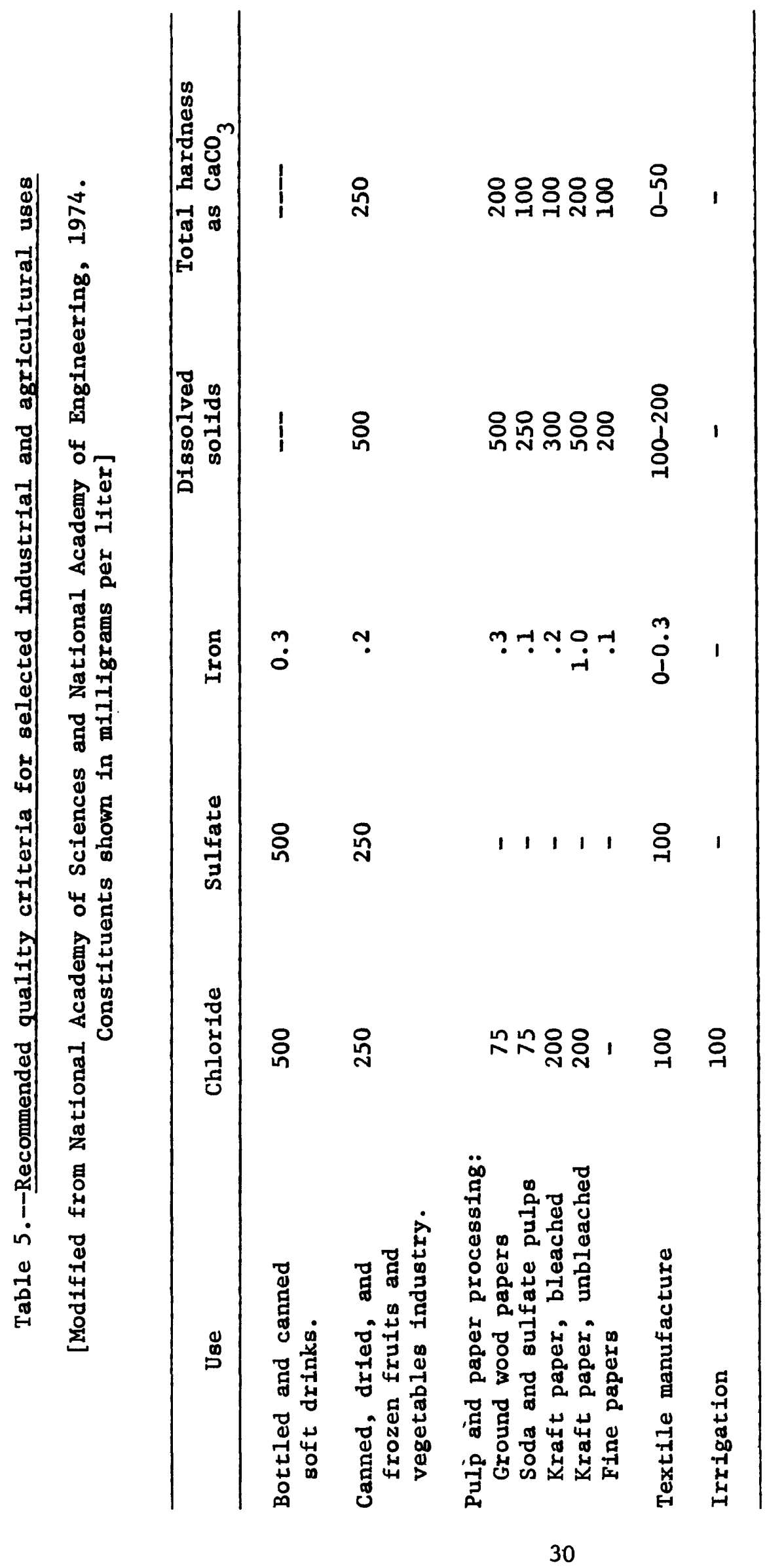


Table 6.--Recommended quality standards for public water supplies

[All constituents are given in milligrams per liter except as indicated]

Chemical substance

Limits not to be exceeded

Physical

Color (platinum-cobalt units)

15

$\mathrm{pH}$

$6.5-8.5$

Chemical

Chloride

250

Fluoride ${ }^{2}$

$1.4-2.4$

Iron

0.3

Nitrate nitrogen

10

Sulfate

250

${ }_{2}^{1}$ Environmental Protection Agency (1975 and 1977a).

2 The concentration of fluoride should be between the limits expressed, depending on the annual average of maximum dally air temperatures at a location being considered. 


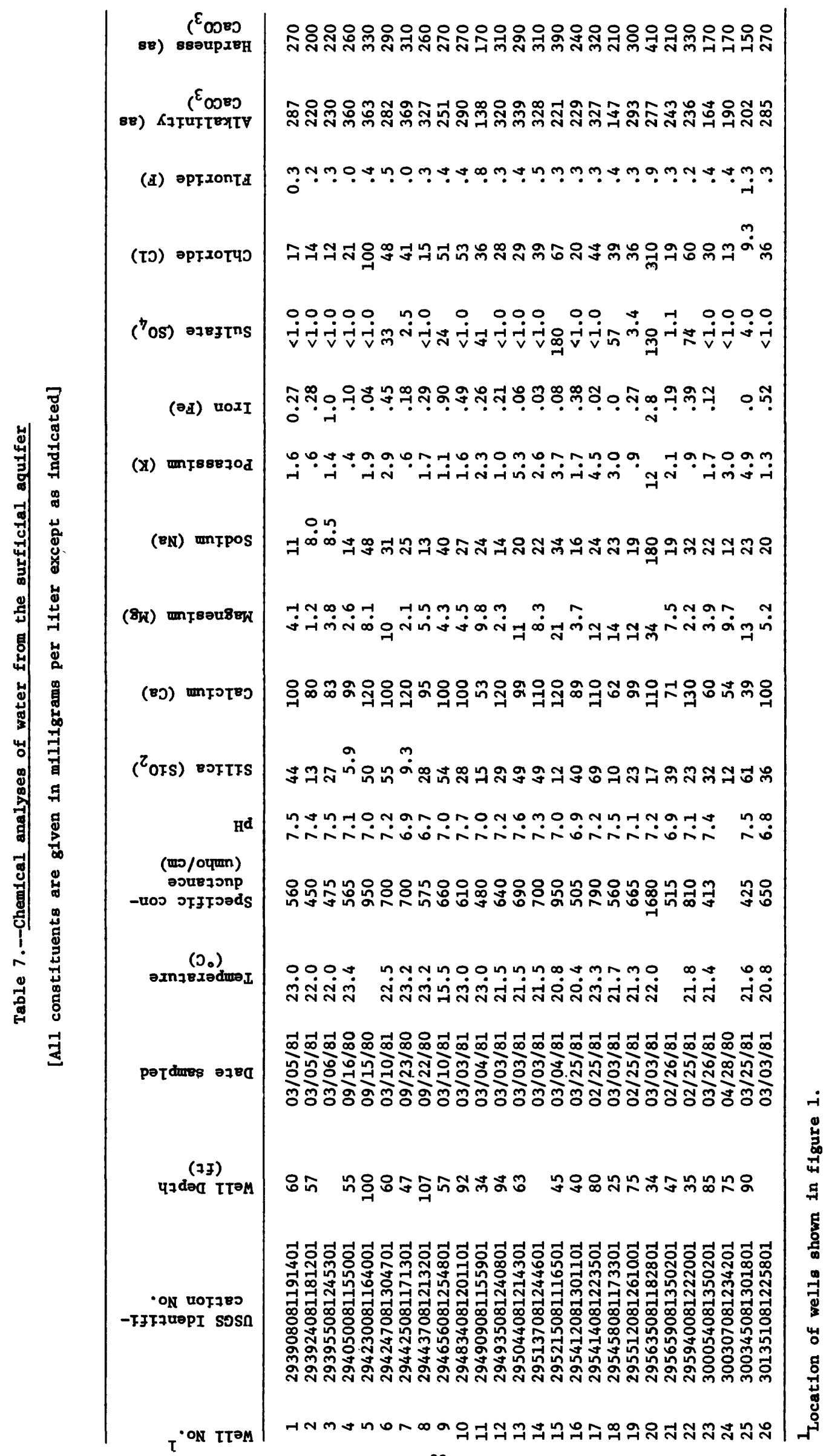




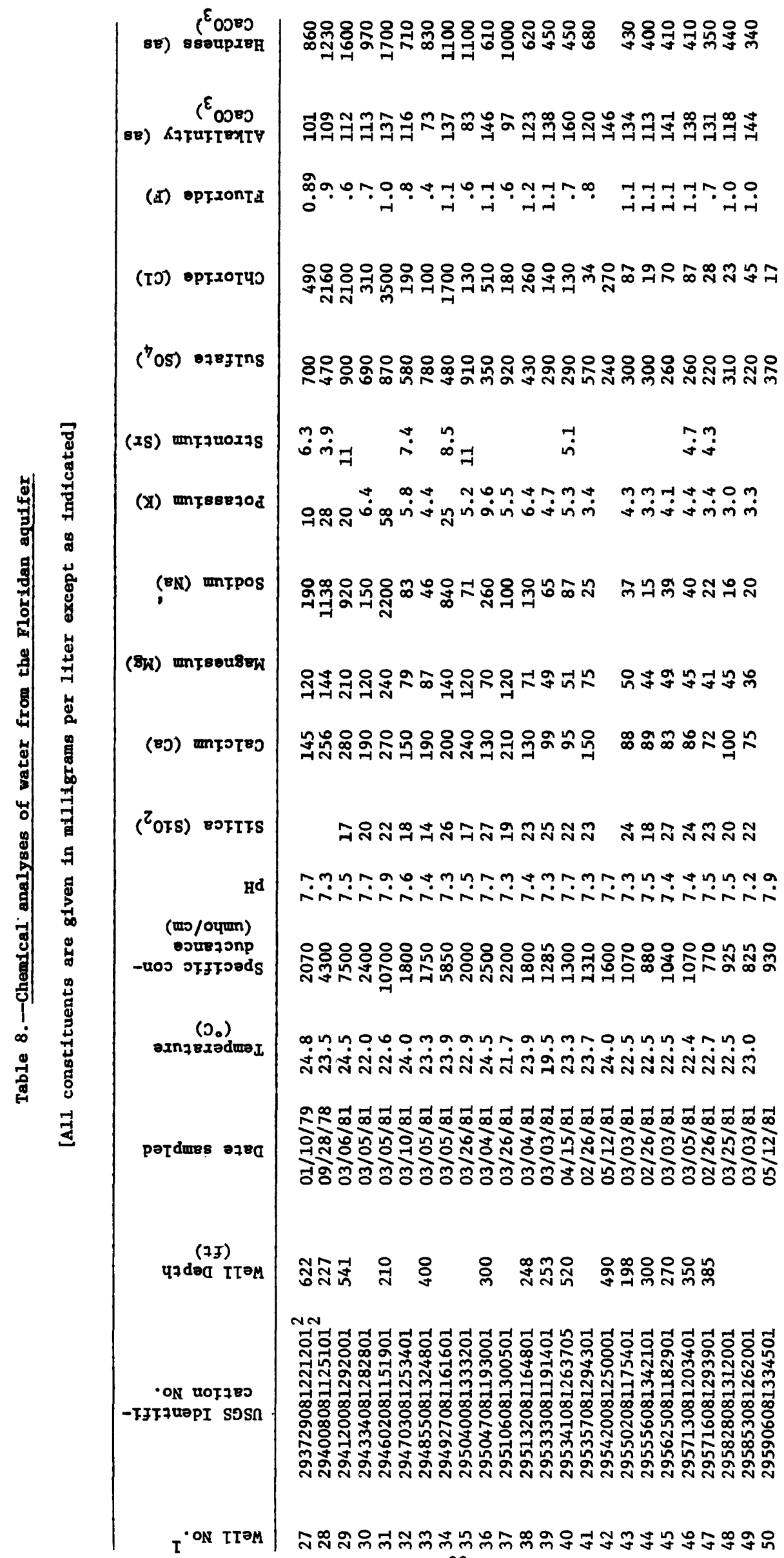




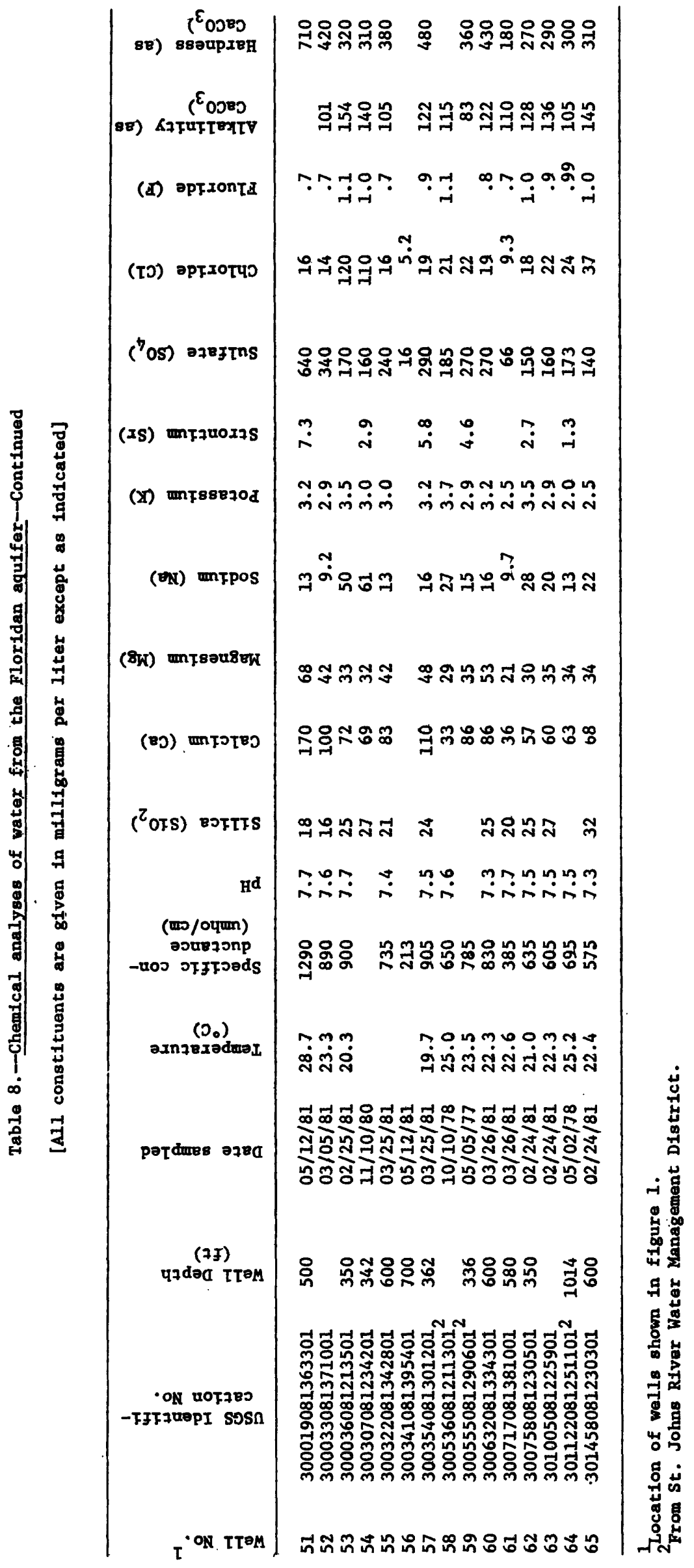


In most of the county, water in the aquifer is a calcium bicarbonate type with chloride concentrations of less than $40 \mathrm{mg} / \mathrm{L}$ and sulfate concentrations of 1 ess than $30 \mathrm{mg} / \mathrm{L}$. The predominance of calcium and bicarbonate Is the result of the dissolution of calcium carbonate $\left(\mathrm{CaCO}_{3}\right)$ minerals which make up the most productive zones of the aquifer. The relatively small quantities of chloride and sulfate found in most of the county are probably contributed by atmospheric precipitation recharging the aquifer or the dissolution of small amounts of residual minerals (Davis and DeWlest, 1966).

Relatively high concentrations of chloride in the surficlal aquifer, exceeding $250 \mathrm{mg} / \mathrm{L}$, are limited to the coastal areas of the county where the aquifer is interconnected with the sea or the Intracoastal Waterway. In a few isolated instances, pumping from the aquifer in these areas has probably induced limited saltwater encroachment; however, no widespread contamination has beèn observed.

Slightly higher concentrations of chloride and sulfate are also found in the surficial aquifer near the farming areas around Hastings and Elkton. In this area, water from the Floridan aquifer is used extensively for agricultural irrigation. The concentrations found in this area could Indicate that the surficial aquifer is' being contaminated to a limited extent by the more saline irrigation water.

Another source of contamination in parts of St. Johns County is uncapped, wild-flowing wells and wells with leaky casings that tap the Floridan aquifer. Saline water flowing from these wells percolates into the surficial aquifer, locally contaminating the ground water. Contamination from wild flowing wells has been observed in northeast St. Johns County at Guana WIldlife Management Area and just north of Matanzas Inlet in the extreme southeastern part of the county (Frazee and McClaugherty, 1979). As of 1982, 12 uncapped wells discharging approximately 1,100 $\mathrm{gal} / \mathrm{min}$ have been located in St. Johns County (A. W. Aikens, St. Johns RIver Water Management District, written commun., 1982).

Iron concentrations exceeding the $0.3 \mathrm{mg} / \mathrm{L}$ standard recommended by the U.S. Environmental Protection Agency (1977a) for drinking water are found throughout the county. Iron concentrations loosely correlate with the presence of hardpan in the aquifer at or near the water table. The hardpan is a well-cemented dark brown-to-black carbonaceous sand which is relatively impermeable. Although no mineralogical analyses of the material are avallable, it does appear to contain significant quantities of Iron oxide as a cementing material. This probably results from the oxidation and subsequent precipitation of dissolved Iron where the water table comes in contact with the atmosphere.

\section{Floridan Aquifer}

In most of St. Johns County, water from the Floridan aquifer is more saline than water from the surficial aquifer. Large variations in the concentrations of dissolved constituents occur both areally and vertically. The results of chemical analyses of water samples from selected wells that tap the Floridan aquifer in St. Johns County are given in table 8 . Locations of sampled wells are shown in figure 1 . 
In much of the northern part of the county, the Floridan aquifer serves as a major source of potable water. It has been estimated that the base of potable water is as deep as 1,250 feet below land surface (Klein, 1971) in the extreme northern part of the county. Most wells, however, penetrate less than 300 feet of the aquifer in order to ayoid producing saline water which often is found in the deeper zones of the aquifer below 300 feet. The upper 300 feet generally corresponds to the Ocala Limestone and the upper part of the Avon Park Limestone.

In most of the southern part of the county, saline water is also present in the upper part of the Floridan aquifer. The concentrations of most constituents in this general area exceed the secondary limits recommended by the U.S. Environmental Protection Agency (1977a) for drinking, and generally limit the use of the water for agricultural purposes.

\section{Specific Conductance}

Figure 12 shows the areal distribution of specific conductance values in water from the upper part of the Floridan aquifer in St. Johns County. The values range from $213 \mathrm{umho} / \mathrm{cm}$ in the extreme northwest part of the county to $10,700 \mathrm{umho} / \mathrm{cm}$ along the southeast coast. Although specific conductance values cannot be used to precisely determine dissolved solids concentrations in natural waters, they do facilitate a practical estimate of the dissolved solids concentrations. For the range of conductances and ground water types found in St. Johns County, multiplication of the specific conductance value by 0.6 to 0.7 gives a reasonable approximation of the dissolved solids concentration $( \pm 100 \mathrm{mg} / \mathrm{L})$. Thus, specific conductance values in figure 12 indicates that water in the southern two-thirds of the county probably exceeds the $500 \mathrm{mg} / \mathrm{L}$ limit for dissolved solids recommended in the National Secondary Drinking Water Regulations (U.S. Environmental Protection Agency, 1977a). Water in much of the northern one-third of the county probably meets the standard for dissolved solids concentrations.

\section{Chloride}

The distribution of dissolved chloride in the upper part of the Floridan aquifer in St. Johns County is shown in figure 13. Concentrations range from less than $10 \mathrm{mg} / \mathrm{L}$ in the northwest part of the county to $3,500 \mathrm{mg} / \mathrm{L}$ in the southeast coastal area. In most of the northern part of the county, the upper part of the Floridan aquifer yields water with chloride concentrations of less than $50 \mathrm{mg} / \mathrm{L}$. In most of the southern half of the county, however, chloride concentrations exceed the $250 \mathrm{mg} / \mathrm{L}$ recommended limit for drinking water (U.S. Environmental Protection Agency, 1977a). This standard is based upon taste considerations rather than health hazards (National Academy of Sciences and National Academy of Engineering, 1974). 


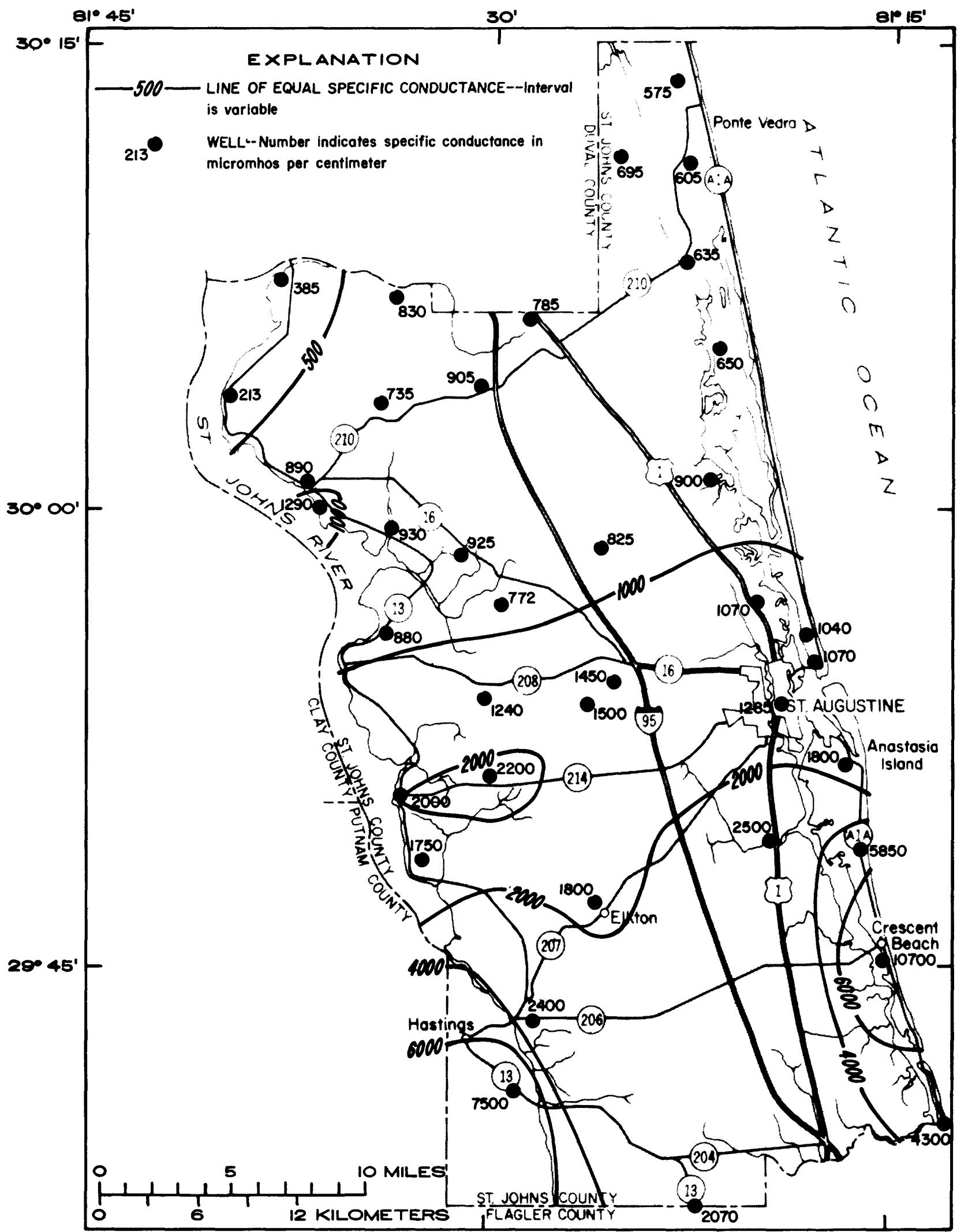

Figure 12.--Distribution of specific conductance of water in the upper part of the Floridan aquifer, 1977-81. 


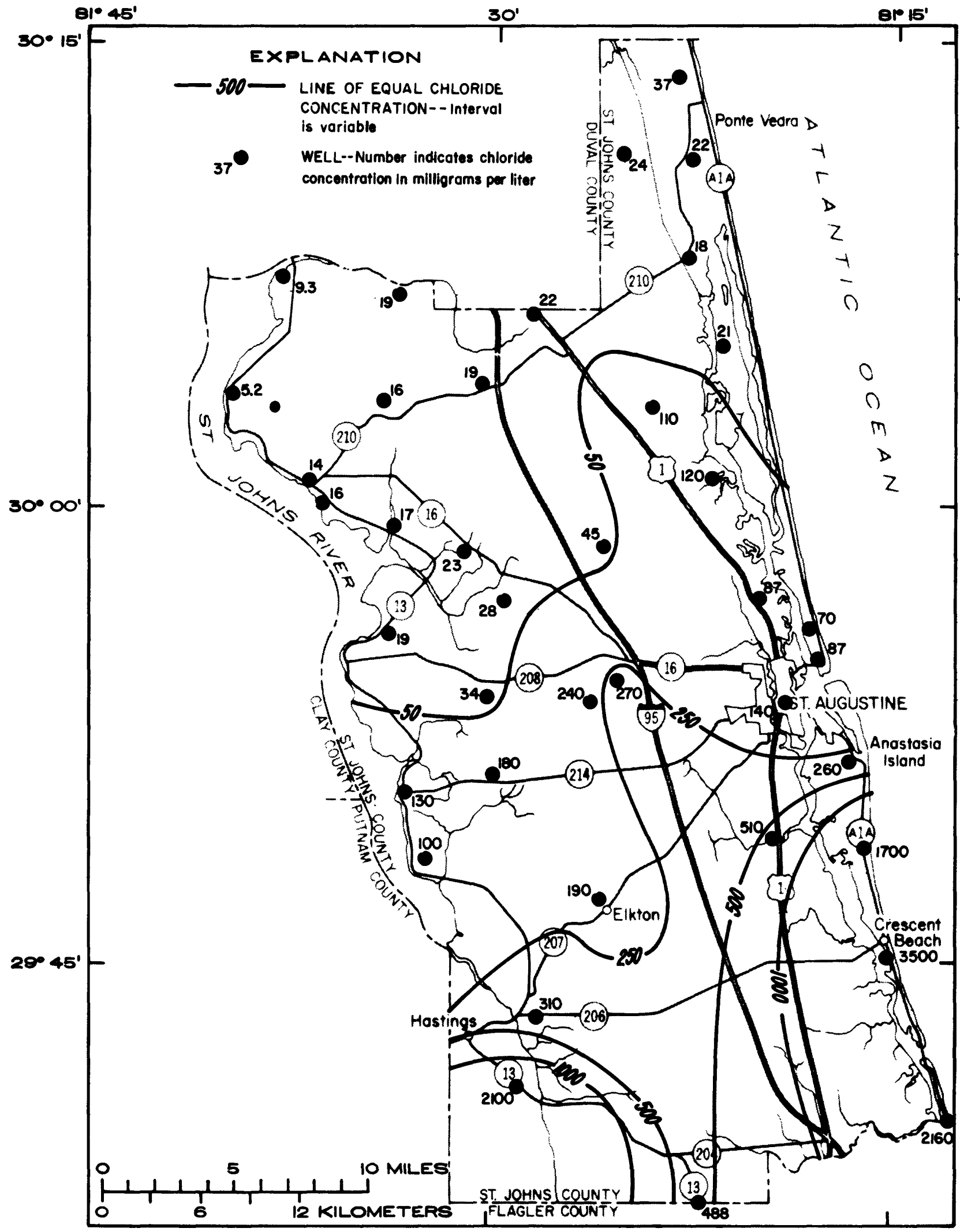

Figure 13.--Distribution of chloride concentrations of water in the upper part of the Floridan aquifer, 1977-81. 
The relatively high chloride concentrations in the upper part of the Floridan aquifer in the southeast part of the county indicate the presence of saline water, which probably entered the aquifer during a high stand of the sea during the Pleistocene and which has not been completely flushed from the aquifer by freshwater (Stringfield and Cooper, 1951, p. 71). In the area north of St. Augustine, saline water was prevented from entering the aquifer by the higher artesian pressure and the thicker confining bed (Stringfield and Cooper, 1951, p. 74). Discharge from the aquifer is occurring through a large submarine spring 2.5 miles east of Crescent Beach and possibly from smaller undetected springs and seeps in this area. This discharge lowers artesian pressures in the upper part of the aquifer and induces the upward migration of saline water from the deep zones within the aquifer (Bermes and others, 1963, p. 88).

Figure 14 shows the chloride concentrations of water from wells that tap the Floridan aquifer prior to 1960 as mapped by Bermes and others, 1963. Comparison of this map with more recent data presented in figure 13 indicates that little change in the chloride concentrations has occurred, however, in the area south of Hastings, chloride concentrations in the upper part of the aquifer have increased. The increases were the result of upward movement of more saline water from deeper in the aquifer in response to lowered artesian pressures in the upper part of the aquifer because of the heavy pumpage for irrigation (Munch and others, 1979a, p. 4). Although water-quality data from wells that tap the deeper zones of the aquifer are limited, Bermes and others (1963) reported that chloride concentrations increase with depth of penetration of the aquifer in most parts of the county.

\section{Sulfate}

The distribution of dissolved sulfate in the upper part of the Floridan aquifer in St. Johns County is shown in figure 15. Concentrations range from $16 \mathrm{mg} / \mathrm{L}$ in the extreme northwest part of the county to $900 \mathrm{mg} / \mathrm{L}$ or more in the southwest and west-central parts of the county. Sulfate concentrations exceed the $250 \mathrm{mg} / \mathrm{L}$ recommended limit for drinking water in most of the county.

High sulfate concentrations are associated with high chloride concentrations in the southern part of the county. This suggests that the high sulfate concentrations are, in part, due to the presence of saline water that has not yet been flushed from the aquifer by freshwater. Comparison of the sulfate to chloride ratios of these waters with the ratio found in seawater, however, indicates that substantial enrichment with sulfate has taken place, probably by the dissolution of sulfate minerals. In most of the northern two-thirds of St. Johns County, sulfate concentrations probably result from the dissolution of gypsum $\left(\mathrm{CaSO}_{4} \cdot 2 \mathrm{H}_{2} \mathrm{O}\right)$ or anhydrite $\left(\mathrm{CaSO}_{4}\right)$.

In two areas along the St. Johns River, sulfate concentrations are much higher than in adjacent areas. The northernmost area corresponds to a depression in the potentiometric surface resulting from natural discharge (figs. 8 and 9). In this area, the high sulfate concentrations could be 


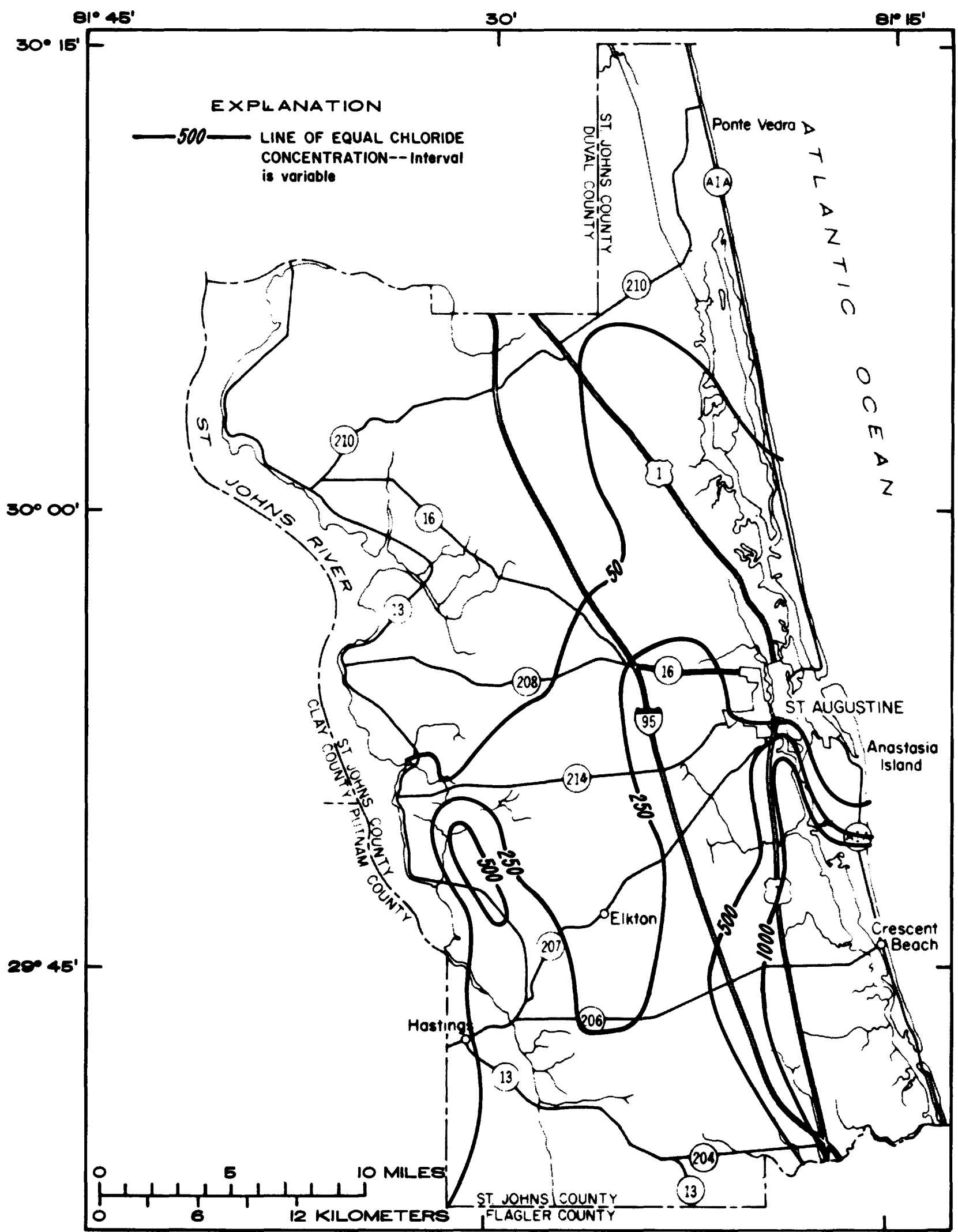

Figure 14.--Distribution of chloride concentrations of water in the upper 200 feet of the Floridan aquifer, pre-1960 (modified from Bermes and others, 1963). 


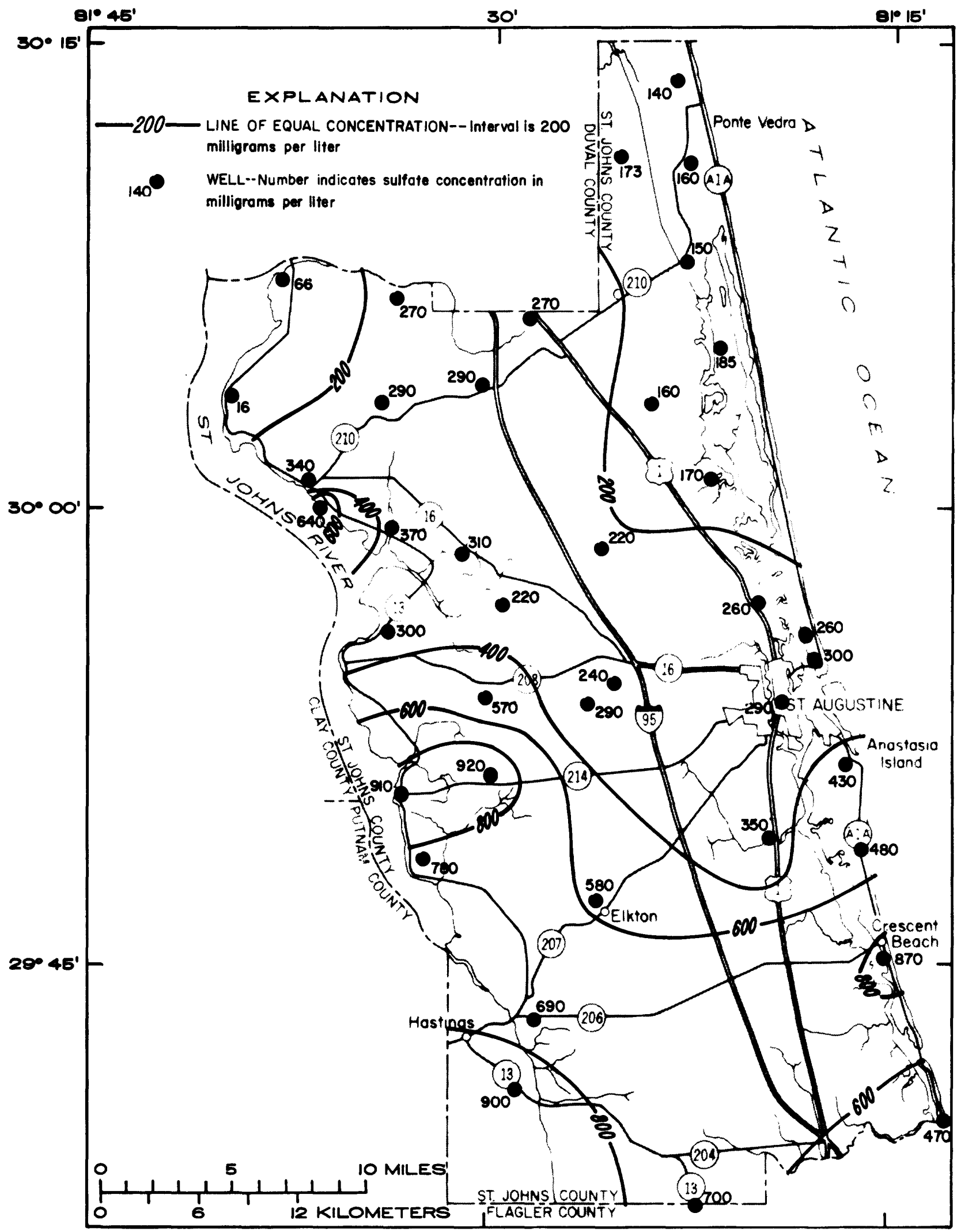

Figure 15.--Distribution of sulfate concentrations of water in the upper part of the Floridan aquifer, 1977-81. 
associated with structural features such as joints and faults which could allow water from deeper zones to move upward (Fairchild, 1977, p. 48). Additional evidence for this mechanism is provided by temperature data for wells 51 and 52 in this area. Well 51, which contains sulfate concentrations of 640 , nearly twice as high as well 52 and other wells in the surrounding area, also yields water that is consistently $6.0^{\circ}$ to $7.0^{\circ} \mathrm{C}$ higher than other wells in the area even though it is only 50 feet deeper. This could indicate that deeper, warmer water with higher sulfate concentrations is migrating upward in this area. Another area where high sulfate concentrations are found in the upper part of the Floridan aquifer is in the west-central part of the county along the St. Johns River.

\section{Total Hardness}

The distribution of total hardness in the upper part of the Floridan aquifer in St. Johns County is shown in figure 16. Concentrations range from less than $200 \mathrm{mg} / \mathrm{L}$ in the northwest part of the county to $17,000 \mathrm{mg} / \mathrm{L}$ in the southeast coastal area. According to the classification scheme presented in table 4, water from the aquifer is classified as very hard in virtually all of the county.

\section{SUMMARY}

In St. Johns County, ground water is obtained both from the surficial and Floridan aquifers. The surficial aquifer is the principal source of water supply for drinking and domestic uses. The aquifer is used extensively as a source of potable water supply for the city of St. Augustine and much of the southern half of the county where water in the Floridan aquifer is saline.

The surficial aquifer underlies all of St. Johns County and generally consists of discontinuous and interbedded lenses of sand, shell, clay, and coquina. It ranges in thickness from about 20 to 120 feet. Water in the surficlal aquifer is generally under water table or unconfined conditions; howeyer, semiconfining conditions can exist locally where clay beds or hardpan are sufficiently thick and continuous. The water table generally conforms to the topography and lies at or near land surface to a depth of about 15 feet below land surface in most of the county. Fluctuations in water leyels occur in response to changes in rates of recharge and discharge. The transmissivity of the aquifer ranges from 1,300 to $18,500 \mathrm{ft}^{2} /$ day. Ylelds from small-diameter wells range from 1 to $40 \mathrm{gal} / \mathrm{min}$.

The chemical quality of the water in the surficial aquifer generally meets the recommended limits set by the U.S. Environmental Protection Agency. The water is hard and sometimes contains objectionable amounts of iron. Concentrations of sulfate and chloride generally do not exceed $250 \mathrm{mg} / \mathrm{L}$ except near the coast and possibly in areas contaminated by water from the Floridan aquifer. 


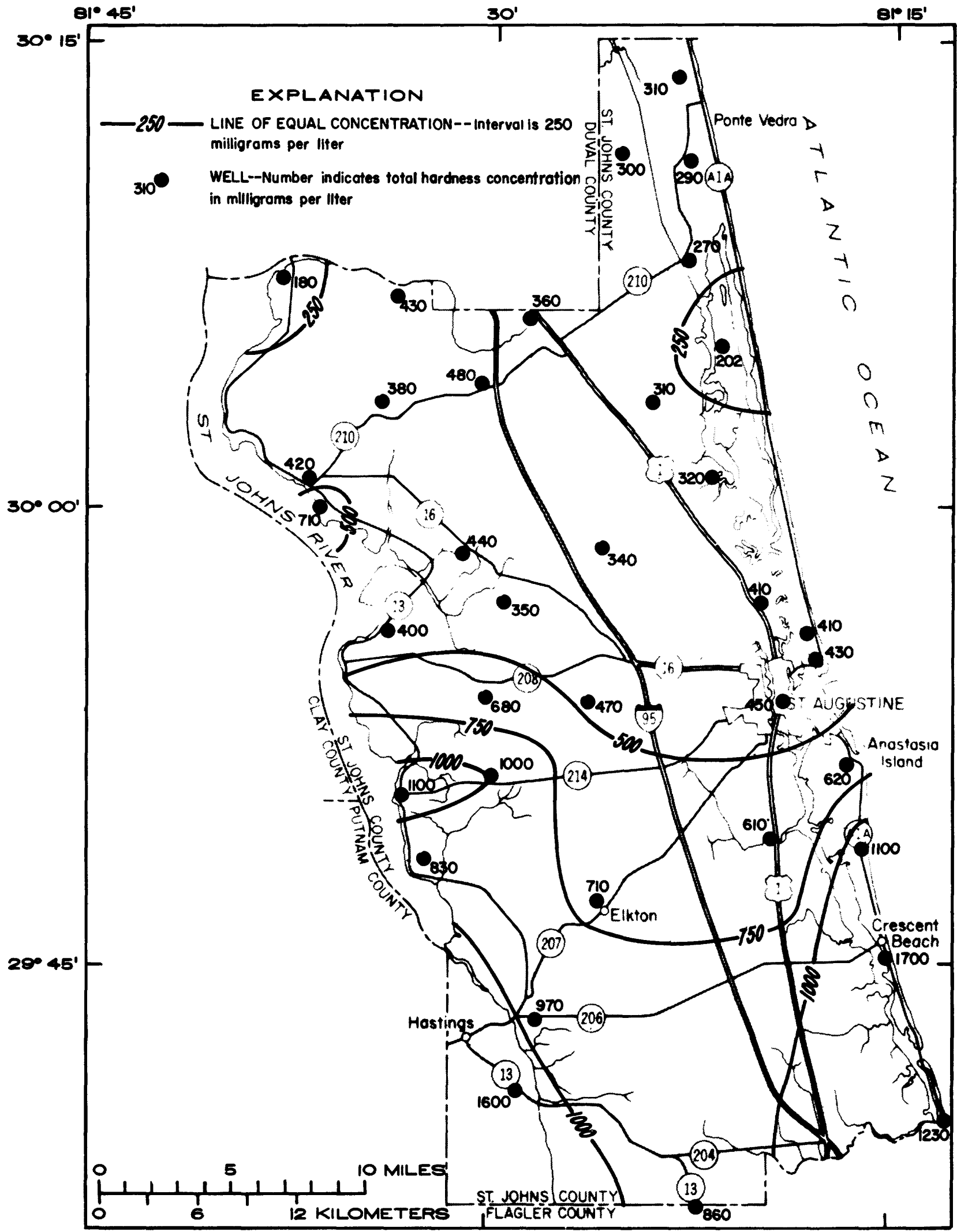

Figure 16.--Distribution of total hardness concentrations of water in the upper part of the Floridan aquifer, 1977-81. 
The Floridan aquifer is the principal source of water supply for irrigation in St. Johns County. In 1980 irrigation accounted for about 79 percent of the total water used in the county. Virtually all of this water was withdrawn from the Floridan aquifer. In the northern half of the county, the Floridan aquifer also serves as a major source of drinking water.

The Floridan aquifer is composed primarily of limestone and dolomite of Eocene age. It is confined by the overlying Hawthorn Formation. The top of the Floridan aquifer is about 90 feet below sea level in the southwestern part of the county, sloping northward to more than 360 feet below sea level in the northern part. Transmissivities for the upper part of the aquifer range from 1,600 to $56,000 \mathrm{ft}^{2} /$ day. Storage coefficients of the aquifer average about $1 \times 10^{-4}$.

The principal recharge area of the Floridan aquifer is an area in the lake region of Alachua, southwestern Clay, eastern Bradford, and western Putnam Counties. The aquifer is recharged primarily by rainfall which enters the Floridan aquifer through breaches in the Hawthorn semiconfining bed caused by sinkholes, by downward leakage where the semiconfining bed is thin or absent, or directly into the aquifer where it is near or at land surface. Water is discharged from the aquifer by springs, pumpage, and by leakage into the overlying surficial aquifer.

The potentiometric surface of the Floridan aquifer fluctuates an average of about 5 feet each year. The potentiometric surface fluctuates primarily in response to rainfall and pumpage and is lowest during May and highest during September. Water levels have declined about 10 to 20 feet over most of the county since development began. Depressions in the potentiometric surface of the Floridan aquifer near Hastings, in the northeast, and the northwest part of the county are the result of either natural discharge by springs or by large-scale withdrawals for irrigation, public, or rural use.

In most of St. Johns County, water in the Floridan aquifer is more saline than water in the surficial aquifer. Variations in the concentrations of chemical constituents in water in the Floridan aquifer occur both areally and vertically. In the northern part of the county, concentrations of most chemical constituents generally meet the U.S. Environmental Protection Agency drinking water standards. In most of the southern part of the county, saline water is present in the upper parts of the aquifer and concentrations of most constituents exceed the limits recommended by the U.S. Environmental Protection Agency for drinking water. The poor quality of the water in this area has limited its use to primarily agricultural irrigation.

In most of the southern part of the county, the presence of relict seawater in the aquifer influences the distribution of chemical constituents. Heavy pumpage for irrigation has resulted in increases in concentrations of most constituents in most of the southwest part of the county. High total hardness and sulfate concentrations in much of the northern part of the county and along the St. Johns River do not appear to be related to the presence of relict seawater, but instead, to the upward movement of ground water and to dissolution of gypsum or anhydrite present in the upper part of the aquifer. 


\section{SELECTED REFERENCES}

American Society for Testing and Materials, 1964, Manual on industrial water and industrial waste water [2d ed.]: Philadelphia, $856 \mathrm{p}$.

Applin, P. L., and Applin, E. R., 1944, Regional subsurface stratigraphy and structure of Florida and southern Georgia: American Association Petroleum Geologists Bulletin, v. 28, no. 12, p. 1673-1753.

Back, W., 1960, Origin of hydrochemical facies of ground water in the Atlantic coastal plain: International Geologic Congress, 21 Session, Part I, Geochemical Cycles, p. 87-95.

Bentley, C. B., 1977, Aquifer test analyses for the Floridan aquifer in Flagler, Putnam, and St. Johns Counties, Florida, 1977: U.S. Geological Suryey Water-Resources Investigations 77-36, $50 \mathrm{p}$.

Bermes, B. J., Leve, G. W., and Tarver, G. R., 1963, Geology and groundwater resources of Flagler, Putnam, and St. Johns Counties, Florida: Florida Geological Survey Report of Investigations No. 32, 97 p.

$\mathrm{CH}_{2} \mathrm{M}$ Hill, 1979, An evaluation of water supply potential from the proposed north well field, Report Number GN15000.90, 63 p.

Chen, C. S., 1965, The regional 1ithostratigraphic analysis of Paleocene and Eocene rocks of Florida: Florida Geological Survey Bulletin 45, 105 p.

Clarke, W. E., Musgrove, R. H., Menke, C. G., and Cagle, J. W., Jr., 1964, Water resources of Alachua, Bradford, Clay, and Union Counties, Florida: Florida Geological Survey Report of Investigations 35, 170 p.

Collins, W. D., and Howard, C. S., 1928, Chemical character of water of Florida: U.S. Geological Survey Water-Supply Paper 596-G, p. 177-233.

Conover, C. S., and Leach, S. D., 1975, River basin and hydrologic unft map of Florida: Florida Bureau of Geology Map Series 72.

Cooke, C. W., 1945, Géology of Florida: Florida Geological Survey Bulletin 29, 339 p.

Cooke, C. W., and Mossom, Stuart, 1929, Geology of Florida: Florida Geological Survey, 20th Annual Report (1927-28), p. 29-227.

Davis, S. N., and Dewiest, R. J. M., 1966, Hydrogeology: New York, John Wiley and Sons, Inc., $448 \mathrm{p}$.

Durfor, C. N., and Becker, Ed1th, 1964, Public water supplies of the 100 largest citles in the United States, 1962: U.S. Geological Survey Water-Supply Paper 1812, 364 p. 
Fairchild, R. W., 1977, Avallability of water in the Floridan aquifer in southern Duval and northern Clay and St. Johns Counties, Florida: U.S. Geological Survey Water-Resources Investigations 76-98, $60 \mathrm{p}$.

Fairchild, R. W., and Bentley, C. B., 1977, Saline-water intrusion in the Floridan aquifer in the Fernandina Beach area, Nassau County, Florida: U.S. Geological Survey Water-Resources Investigations 77-32, 27 p.

Ferris, J. G., Knowles, D. B., Brown, R. H., and Stallman, R. W., 1962, Theory of aquifer tests: U.S. Geological Survey Water-Supply Paper 1536-E, $174 \mathrm{p}$.

Florida Board of Conservation, 1966, Division of Water Resources: Gazetteer of Florida Streams.

Frazee, J. M., Jr., and McClaugherty, D. R., 1979, Investigation of ground-water resources and saltwater intrusion in the coastal areas of northeast Florida: St. Johns River Water Management District Technical Report No. 3, 136 p.

Geraghty and Miller, Inc., 1976, Development of ground-water resources on Anastasia Island, Florida: Tampa, Florida.

Hampson, P. S., and Hayes, E. C., 1982, Chloride and total hardness concentrations of water from the upper part of the Floridan aquifer in St. Johns County, Florida: U.S. Geological Survey Open-File Report 81-907.

Hayes, E. C., 1981, The surficial aquifer in east-central St. Johns County, Florida: U.S. Geological Survey Water-Resources Investigations $81-14,19 \mathrm{p}$.

Hem, J. D., 1970, Study and interpretation of the chemical characteristics of natural water: U.S. Geological Survey Water-Supply Paper 1473, 363 p.

Horr, C. A., 1959, A survey of analytical methods for the determination of strontium in natural water: U.S. Geological Survey Water-Supply Paper 1496A, p. 1-8.

Johnston, R. H., Krause, R. E., Meyer, F. W., Ryder, P. D., Tibbals, C. H., and Hunn, J. D., 1980, Estimated potentiometric surface for the Tertiary limestone aquifer system, southeastern United States, prior to development: U.S. Geological Survey Open-File Report 80-406.

Klein, Howard, 1971 [1975], Depth to base of potable water in the Floridan aquifer: Florida Bureau of Geology Map Series 42. 
Leach, S. D., 1982a, Estimated water use in Florida, 1980: Florida Bureau of Geology Map Series 103.

Leach, S. D., 1982b, Source, use, and disposition of water in Florida, 1980: U.S. Geological Survey Water-Resources Investigations 82-4090, 337 p.

Leve, G. W., 1966, Ground water in Duval and Nassau Counties, Florida: Florida Geological Survey Report of Investigations 43, 91 p.

1968, The Floridan aquifer in northeast Florida: Ground Water, v. 6, no. 2, p. 19-29.

Lohman, S. W., 1979, Ground water hydraulics: U.S. Geological Survey Professional Paper 708, 70 p.

Lohman, S. W., and others, 1972, Definition of selected ground-water terms--revisions and conceptual refinements: U.S. Geological Survey Water-Supply Paper 1988, 21 p.

Marella, Richard, 1982, Annual water use survey: 1980: St. Johns River Water Management District Technical Report no. 14, 165 p.

Marth, Del, and Marth, M. J., eds., 1980, The 1980-81 Florida Almanac: San Diego, Calif., A. S. Barnes and Co., Inc., p. 150.

Matson, G. C., and Sanford, Samue1, 1913, Geology and ground waters of Florida: U.S. Geological Survey Water-Supply Paper 319, 445 p.

Munch, D. A., Ripy, B. J., and Johnson, R. A., 1979a, Saline contamination of a limestone aquifer by connate intrusion in agricultural areas of St. Johns, Putnam, and Flagler Counties, northeast Florida: St. Johns River Water Management District Technical Report No. 2, 89 p.

$1979 \mathrm{~b}$, Supplemental data for report of saline contamination of a limestone aquifer by connate intrusion in agricultural areas of St. Johns, Putnam, and Flagler Counties, northeast Florida: St. Johns River Water Management District Technical Memorandum No. $2,75 \mathrm{p}$.

National Academy of Sciences and National Academy of Engineering, 1974, Water quality criteria, 1972: U.S. Environmental Protection Agency Report EPA R3-73-033, 594 p.

National Oceanic and Atmospheric Administration, 1973, Monthly normals of temperature, precipitation, and heating and cooling degree days 19411970: Climatography of the United States no. 81.

Puri, H. S., 1957, Stratigraphy and zonation of the Ocala Group: Florida Geological Survey Bulletin 38, 248 p. 
Puri, H. S., and Vernon, R. 0., 1964, Summary of the geology of Florida and a guidebook of the classic exposures: Florida Geological Survey Special Publication 5, 312 p.

Schiner, G. R., and Hayes, E. C., 1980, Potentiometric surface map of the Floridan aquifer in the St. Johns River Water Management District and vicinity, Florida, September 1980: U.S. Geological Survey Open-File Report 81-136.

1981, Potentiometric surface of the Floridan aquifer, St. Johns River Water Management District and vicinity, Florida, May 1981: U.S. Geological Survey Open-File Report 81-1052.

Sellards, E. H., 1907, Occurrence and use of artesian water: Agricultural Experiment Station Bulletin 89, p. 113.

Sellards, E. H., and Gunter, Herman, 1913, The artesian water supply of eastern and southern Florida: Florida Geological Survey Fifth Annual Report, p. 103-306.

Spechler, R. M., 1984, Altitude and generalized configuration of the top of the Floridan aquifer, St. Johns County, Florida: U.S. Geological Survey Water-Resources Investigations 83-4101, 1 sheet.

Stringfield, $\nabla$. T., 1936, Artesian water in the Florida peninsular: U.S. Geological Survey Water-Supply Paper 773-C, p. 115-195.

1966, Artesian water in Tertiary 1imestone in the southeastern states: U.S. Geological Survey Professional Paper 517, 226 p.

Stringfield, V. T., and Cooper, H. H., Jr., 1951, Geologic and hydrologic features of an artesian spring east of Florida: Florida Geological Survey Report of Investigations 7, pt. 2, p. 61-72.

Tarver, G. R., 1958, Interim report on the ground-water resources of St. Johns County, Florida: Florida Geological Survey Information Circular 14, $36 \mathrm{p}$.

Theis, C. V., 1963, Estimating the transmissibility of a water-table aquifer from the specific capacity of a well, in Bentall, Ray, compiler, Methods of determining permeability, transmissibility and drawdown: U.S. Geological Survey Water-Supply Paper 1536-I, p. 332336.

U.S. Department of Commerce, Bureau of the Census, 1982: 1980 Census of Population: Number of Inhabitants, Florida, PC 80-1-A11.

U.S. Environmenta1 Protection Agency, 1975, National interim primary drinking water regulations: Federal Register, v: 40, no. 248, Wednesday, December 24, 1975, Part IV, p. 59566-59587.

1977a, National secondary drinking water regulations: Federal Register, v. 42, no. 62, Thursday, March 31, 1977, Part I, p. 17143-17147. 
1977b, Quality criterla for water, 1976: U.S. Environmental Protection Agency Publication, 256 p.

U.S. Geological Survey, 1978, Water resources data for Florida, v. 4, nor thwest Florida, Water Year 1978, p. 11-16.

Unklesby, A. G., 1945, Ground-water Investigation at St. Augustine, Florida: U.S. Geological Survey Open-File Report FL-45001, 57 p.

Vernon, R. 0., 1951, Geology of Citrus and Levy Counties, Florida: FlorIda Geological Survey Bulletin 33, 256 p.

Vernon, R. 0., and Puri, H. S., 1965, Geologic map of Florida: Florida Board of Conservation, Division of Geology Map Series, no. 18, 1 sheet. 